\title{
Development of highly potent melanogenesis inhibitor by in vitro, in vivo and computational studies
}

\author{
Qamar Abbas' \\ Zaman Ashraf ${ }^{2}$ \\ Mubashir Hassan' \\ Humaira $\mathrm{Nadeem}^{3}$ \\ Muhammad Latif ${ }^{4}$ \\ Samina Afzal ${ }^{5}$ \\ Sung-Yum Seo' \\ 'Department of Biology, College of \\ Natural Sciences, Kongju National \\ University, Gongju, Republic of \\ Korea; ${ }^{2}$ Department of Chemistry, \\ Allama Iqbal Open University, \\ Islamabad, ${ }^{3}$ Riphah Institute of \\ Pharmaceutical Sciences, Riphah \\ International University, Islamabad, \\ Pakistan; ${ }^{4}$ Center for Genetics and \\ Inherited Diseases, Taibah University, \\ Almadinah Almunawwarah, Kingdom \\ of Saudi Arabia; ${ }^{5}$ Faculty of Pharmacy, \\ Bahauddin Zakria University, Multan, \\ Pakistan
}

This article was published in the following Dove Press journal:

Drug Design, Development and Therapy

5 July 2017

Number of times this article has been viewed
Abstract: The present work describes the synthesis of few hydroxylated amide derivatives as melanogenesis inhibitors. In vitro, in vivo and computational studies proved that compound $\mathbf{6 d}$ is a highly potent melanogenesis inhibitor compared to standard kojic acid. The title amides $4 \mathbf{a}-\mathbf{e}$ and $\mathbf{6 a}-\mathbf{e}$ were synthesized following simple reaction routes with excellent yields. Most of the synthesized compounds exhibited good mushroom tyrosinase inhibitory activity, but compound 6d showed excellent activity $\left(\mathrm{IC}_{50} 0.15 \mu \mathrm{M}\right)$ compared to standard kojic acid $\left(\mathrm{IC}_{50} 16.69 \mu \mathrm{M}\right)$. Lineweaver-Burk plots were used for the determination of kinetic mechanism, and it was found that compounds $\mathbf{4} \mathbf{c}$ and $\mathbf{6} \mathbf{d}$ showed non-competitive inhibition while $\mathbf{6 a}$ and $\mathbf{6 b}$ showed mixedtype inhibition. The kinetic mechanism further revealed that compound $\mathbf{6 d}$ formed irreversible complex with the target enzyme tyrosinase. The $K i$ values determined for compounds $\mathbf{4 c}, \mathbf{6 a}, \mathbf{6} \mathbf{b}$ and $6 \mathbf{d}$ are $0.188,0.84,2.20$ and $0.217 \mu \mathrm{M}$ respectively. Results of human tyrosinase inhibitory activity in A375 human melanoma cells showed that compound 6d exhibited 91.9\% inhibitory activity at a concentration of $50 \mu \mathrm{g} / \mathrm{mL}$. In vivo cytotoxicity evaluation of compound $\mathbf{6 d}$ in zebrafish embryos showed that it is non-toxic to zebrafish. Melanin depigmentation assay performed in zebrafish indicated that compound $\mathbf{6} \mathbf{d}$ possessed greater potential in decreasing melanin contents compared to kojic acid at the same concentration. Computational studies also supported the wet lab findings as compound $\mathbf{6 d}$ showed a highest binding affinity with the target protein (PDBID: 2Y9X) with a binding energy value of $-7.90 \mathrm{kcal} / \mathrm{mol}$. Molecular dynamic simulation studies also proved that amide $\mathbf{6} \mathbf{d}$ formed the most stable complex with tyrosinase. Based upon our in vitro, in vivo and computational studies, we propose that compound $\mathbf{6} \mathbf{d}$ is a promising candidate for the development of safe cosmetic agent.

Keywords: melanogenesis, computational studies, tyrosinase inhibition, zebrafish, melanin quantification

\section{Introduction}

Melanogenesis, the process of skin color formation, is controlled by a complex molecular regulatory network embedded in the keratinocytes and melanocytes, which results in the skin and hair pigmentation. ${ }^{1-3}$ Melanin biosynthesis in melanosomes is regulated by a copper-containing metalloenzyme tyrosinase. Tyrosine in the presence of tyrosinase is converted into melanin through a series of biochemical reactions., ${ }^{4,5}$ L-tyrosine and L-3,4-dihydroxyphenylalanine (L-DOPA) are the important substrates involved in melanin biosynthesis. ${ }^{6-8}$ The presence of melanins in the surrounding keratinocytes is the important factor that determines the color of the human skin..$^{9,10}$

Ultraviolet exposure, $\alpha$-melanocyte-stimulating hormone, melanocortin 1 receptor and agouti-related protein are some of the other factors involved in melanogenesis. ${ }^{11,12}$ 
Melanogenesis corresponds to a possible cellular danger and is confined to special melanosomes in melanocytes, which synthesize pigments and transfer them to recipient cells. ${ }^{13}$ The abnormal proliferation of melanocytes results in melanoma, a type of skin cancer. ${ }^{14,15}$ Melasma and post-inflammatory disorders are examples of hyperpigmentation disorders for which patients pursue treatment. ${ }^{16}$

Higher quantity of tyrosinase activity can also be linked to neurodegenerative diseases due to $o$-quinones formation by oxidation of dopamine results in neuronal damage and cell death. ${ }^{17-19}$ The agents that are clinically used for hyperpigmentation disorders are usually associated with side effects. Therefore, there arises a need to develop some novel melanogenesis inhibitors with decreased side effects. A number of hydroxy-substituted aromatic acids and esters have been reported as potent melanogensis inhibitors. ${ }^{20-23}$ Takahashi and Miyazawa also reported the potential of hydroxylated amides and analogues to potentially inhibit melanogenesis. ${ }^{24}$ The present work describes the synthesis of hydroxylated amides and their melanogenesis potency.

\section{Materials and methods}

\section{Chemicals}

2-amino- $p$-cymene, mushroom tyrosinase, L-DOPA and other required chemicals were purchased from SigmaAldrich, St Louis, MO, USA. Melting points were determined using a Digimelt MPA 160 melting point apparatus and are reported uncorrected. FTIR spectra were recorded using Shimadzu FTIR-8400S spectrometer (Kyoto, Japan; $\left.v, \mathrm{~cm}^{-1}\right) .{ }^{1} \mathrm{H}$ NMR and ${ }^{13} \mathrm{C}$ NMR spectra (DMSO- $d_{6}$ ) were recorded using a Bruker $400 \mathrm{MHz}$ spectrometer (Brüker
Biospin, Switzerland). Chemical shifts $(\delta)$ were reported in parts per million (ppm) downfield from the internal standard tetramethylsilane. The purity of the compounds was checked by thin layer chromatography (TLC) on silica gel plate using n-hexane and ethyl acetate as mobile phase.

\section{Synthesis of 2-chloro-N-[2-methyl-5- (propan-2-yl)phenyl]acetamide (2)}

2-amino- $p$-cymene $\mathbf{1}(0.01 \mathrm{~mol})$ and triethylamine $(0.01 \mathrm{~mol})$ were reacted with chloroacetyl chloride $(0.01 \mathrm{~mol})$ in anhydrous dichloromethane $(25 \mathrm{~mL})$ at $0^{\circ} \mathrm{C}$ to $-5^{\circ} \mathrm{C}$. The reaction mixture was stirred over a period of $1 \mathrm{~h}$ at constant temperature. The reaction mixture was then stirred at room temperature for further $5 \mathrm{~h}$ and progress of the reaction was determined by TLC. The mixture was washed with $5 \% \mathrm{HCl}$ and 5\% sodium hydroxide solution; the organic layer was washed with saturated aqueous $\mathrm{NaCl}$, dried over anhydrous magnesium sulfate, filtered and the solvent was removed under reduced pressure. The crude 2-chloro-N-[2-methyl-5(propan-2-yl)phenyl]acetamide 2 was recrystallized in ethanol as needle-like crystals: melting point $94^{\circ} \mathrm{C}-96^{\circ} \mathrm{C}$; yield $82 \% ; \mathrm{R}_{\mathrm{f}}=0.54$ (n-hexane: ethyl acetate $2: 1$ ); FTIR $v_{\text {max }} \mathrm{cm}^{-1}$ : 3,354 (N-H), 2,987 (sp2 C-H), 2,893 (sp3 C-H), 1,656 (C=O ester), 1,598 ( $\mathrm{C}=\mathrm{C}$ aromatic), 1,140 (C-O, ester).

\section{Synthesis of amide derivatives (4a-e) and (6a-e)}

The hydroxy-substituted benzoic acids $\mathbf{3 a}-\mathbf{e}(0.01 \mathrm{~mol})$, triethyl amine $(0.01 \mathrm{~mol})$, potassium iodide $(0.01 \mathrm{~mol})$ in dimethyl formamide $(25 \mathrm{~mL})$ and intermediate $2(0.01 \mathrm{~mol})$ were stirred overnight at room temperature (Scheme 1).<smiles>Cc1ccc(C(C)C)cc1N</smiles>

(1)<smiles>[R]c1ccc(C(=O)O)cc1</smiles>

(2)
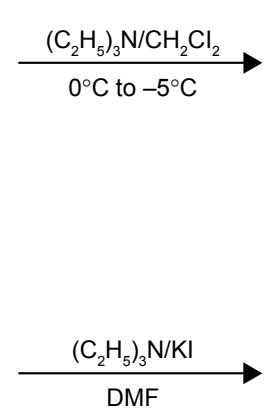

DMF<smiles>Cc1ccc(C(C)C)cc1NC(=O)CCl</smiles>

(2)<smiles>[R]CC(C)c1ccc(C)c(NC(=O)COC(=O)c2ccccc2)c1</smiles>

$R$ is same as in (3a-e)

$$
\begin{array}{ll}
3 a=3-O H & 3 b=4-O H \\
3 c=2,4-d i-O H & 3 d=3,4-d i-O H \\
3 e=3,5-d i-O H &
\end{array}
$$

Scheme I Synthesis of amide derivatives (4a-e).

Abbreviation: DMF, dimethylformamide. 
After the completion of reaction, the mixture was poured into finely crushed ice by stirring and extracted with ethyl acetate $(4 \times 25 \mathrm{~mL})$. The combined organic layer was washed with $5 \% \mathrm{HCl}, 5 \%$ sodium hydroxide and finally with aqueous $\mathrm{NaCl}$ solution. The organic layer was dried over anhydrous magnesium sulfate, filtered and the solvent was removed under reduced pressure to afford the crude products $4 \mathbf{a}-\mathbf{e}$. The title compounds $\mathbf{4 a}-\mathbf{e}$ were purified by silica gel column chromatography (n-hexane: ethyl acetate $3: 1$ ). The compounds $\mathbf{6 a}-\mathbf{e}$ were prepared by reacting intermediate $\mathbf{2}$ with substituted cinnamic acids $\mathbf{5 a}-\mathbf{e}$ (Scheme 2). The reaction conditions were same as described for the preparation of compounds $\mathbf{4 a}-\mathbf{e}$.

\section{2-[2-methyl-5-(propan-2-yl)anilino]-2- oxoethyl 3-hydroxybenzoate (4a)}

Yield, $85 \%$; melting point, $116^{\circ} \mathrm{C}-118^{\circ} \mathrm{C}$; $\mathrm{R}_{\mathrm{f}}=0.56$ (nhexane:ethyl acetate $2: 1)$; FTIR $v_{\max } \mathrm{cm}^{-1}: 3,354(\mathrm{~N}-\mathrm{H}), 3,166$ (O-H), 2,987 (sp2 C-H), 2,913 (sp3 C-H), 1,735 ( $\mathrm{C}=\mathrm{O}$ ester), 1,657 ( $\mathrm{C}=\mathrm{O}$ amide), 1,590 ( $\mathrm{C}=\mathrm{C}$ aromatic), 1,149 $(\mathrm{C}-\mathrm{O}$, ester); ${ }^{1} \mathrm{H}$ NMR (DMSO- $d_{6}, \delta$ ppm): 8.63 (s, 1H, -NH), 7.76 (d, $J=6.8 \mathrm{~Hz}, 1 \mathrm{H}, \mathrm{H}-6), 7.52$ (s, 1H, H-2), 7.42 (dd, $J=6.8,7.6$ Hz, 1H, H-5), 7.36 (d, J=7.6 Hz, 1H, H-4), 7.14 (d, J=2.4 Hz, 1H, H-3'), 7.05 (d, J=7.6 Hz, 1H, H-4'), 6.96 (s, 1H, H-6'), 4.98 (s, 2H, $-\mathrm{CH}_{2}$ ), 3.06 (sept, 1H, J=6.5 Hz, H-1"), 2.32 (s, 3H, H-3"), 1.36 (s, 1H, -OH), 1.25 (d, J=6.5 Hz, 6H, $\left.\mathrm{H}-2{ }^{\prime \prime}\right) ;{ }^{13} \mathrm{C} \mathrm{NMR}\left(\mathrm{CDCl}_{3}, \delta \mathrm{ppm}\right) ; 165.6$ (C=O ester), 162.5 (C=O, amide), 152.4 (C-3), 144.7 (C-1'), 138.6 (C-2'), 136.4 (C-5'), 133.6 (C-6), 131.3 (C-2), 129.6 (C-1), 127.6 (C-3'), 124.5 (C-4'), 122.3 (C-6'), 120.8 (C-4), 116.4 (C-5), 60.3 $\left(-\mathrm{CH}_{2}\right), 27.4\left(\mathrm{C}-1^{\prime \prime}\right), 26.5\left(\mathrm{C}-3^{\prime \prime}\right), 20.3\left(\mathrm{C}-2^{\prime \prime}\right)$.

\section{2-[2-methyl-5-(propan-2-yl)anilino]-2- oxoethyl 4-hydroxybenzoate (4b)}

Yield, $80 \%$; melting point, $121^{\circ} \mathrm{C}-123^{\circ} \mathrm{C}$; $\mathrm{R}_{\mathrm{f}}=0.53$ (nhexane:ethyl acetate 2:1); FTIR $v_{\max } \mathrm{cm}^{-1}: 3,332(\mathrm{~N}-\mathrm{H})$, 3,153 (O-H), 2,966 (sp2 C-H), 2,901 (sp3 C-H),
$1,732(\mathrm{C}=\mathrm{O}$ ester), 1,645 ( $\mathrm{C}=\mathrm{O}$ amide), 1,593 ( $\mathrm{C}=\mathrm{C}$ aromatic), 1,148 (C-O, ester); ${ }^{1} \mathrm{H}$ NMR (DMSO- $d_{6}, \delta$ ppm): 8.64 (s, 1H, -NH), 8.12 (dd, J=7.6, 2.4 Hz, 2H, H-2, H-6), 7.34 (d, $\left.J=2.2 \mathrm{~Hz}, 1 \mathrm{H}, \mathrm{H}-2^{\prime}\right), 7.19$ (dd, $J=7.6,2.2 \mathrm{~Hz}, 1 \mathrm{H}$, H-4'), 7.04 (d, J=7.6, 1H, H-6'), 6.92 (dd, $J=7.6,2.2 \mathrm{~Hz}$, 2H, H-3, H-5), 5.01 (s, 2H, - $\mathrm{CH}_{2}$ ), 4.93 (s, 1H, - OH), 2.72 (sept, J=6.4 Hz, 1H, H-1"), 2.22 (s, 3H, -H-3"), 1.24 (d, $\left.J=6.4 \mathrm{~Hz}, 6 \mathrm{H}, \mathrm{H}-2 "{ }^{\prime \prime}\right) ;{ }^{13} \mathrm{C}$ NMR (DMSO- $\left.d_{6} \delta \mathrm{ppm}\right) ; 164.5$ ( $\mathrm{C}=\mathrm{O}$ ester), 160.2 ( $\mathrm{C}=\mathrm{O}$, amide), $154.5(\mathrm{C}-4), 149.7\left(\mathrm{C}-1^{\prime}\right)$, 139.5 (C-2'), 136.5 (C-5'), 133.6 (C-3, C-5), 130.4 (C-1), 128.3 (C-3'), 126.4 (C-4'), 123.5 (C-6'), 119.4 (C-2, C-6), $61.4\left(-\mathrm{CH}_{2}\right), 28.5\left(\mathrm{C}-1^{\prime \prime}\right), 26.8\left(\mathrm{C}-3^{\prime \prime}\right), 21.9\left(\mathrm{C}-2^{\prime \prime}\right)$.

\section{2-[2-methyl-5-(propan-2-yl)anilino]-2- oxoethyl 2,4-dihydroxybenzoate (4c)}

Yield, 78\%; melting point, $136^{\circ} \mathrm{C}-138^{\circ} \mathrm{C}$; $\mathrm{R}_{\mathrm{f}}=0.44$ (nhexane:ethyl acetate 2:1); FTIR $v_{\max } \mathrm{cm}^{-1}: 3,364(\mathrm{~N}-\mathrm{H})$, 3,163 (O-H), 2,966 (sp2 C-H), 2,895 (sp3 C-H), 1,728 ( $\mathrm{C}=\mathrm{O}$ ester), 1,651 ( $\mathrm{C}=\mathrm{O}$ amide), 1,590 ( $\mathrm{C}=\mathrm{C}$ aromatic $)$, $1,160\left(\mathrm{C}-\mathrm{O}\right.$, ester); ${ }^{1} \mathrm{H}$ NMR (DMSO- $d_{6}, \delta$ ppm): 8.64 (s, 1H, -NH), 7.64 (d, J=7.4 Hz, 1H, H-6), 7.19 (d, J=7.4 Hz, 1H, H-5), 7.11 (d, J=2.2 Hz, 1H, H-6'), 6.89 (s, 1H, H-3), 6.42 (d, $\left.J=7.6 \mathrm{~Hz}, 1 \mathrm{H}, \mathrm{H}-3^{\prime}\right), 6.31$ (dd, $J=7.6,2.2 \mathrm{~Hz}, 1 \mathrm{H}$, H-4'), 5.11 (s, 2H, $-\mathrm{CH}_{2}$ ), 4.67 (s, 2H, $\left.-\mathrm{OH}\right), 2.850$ (sept, $\left.J=7.1 \mathrm{~Hz}, 1 \mathrm{H}, \mathrm{H}-1^{\prime \prime}\right), 2.09$ (s, 3H, H-3"), 1.13 (d, J=7.1 Hz, $\left.6 \mathrm{H}, \mathrm{H}-2^{\prime \prime}\right) ;{ }^{13} \mathrm{C}$ NMR (DMSO- $\left.d_{6}, \delta \mathrm{ppm}\right) ; 166.5$ (C=O ester), 162.1 (C=O amide), 160.3 (C-2), 155.6 (C-4), 148.2 (C-1'), 138.5 (C-2'), 136.3 (C-5'), 134.6 (C-6), 129.9 (C-4'), 127.7 (C-3'), 120.8 (C-6'), 112.3 (C-3), 108.3 (C-5), 105.1 (C-1), $59.3\left(-\mathrm{CH}_{2}\right), 29.1\left(\mathrm{C}-1^{\prime \prime}\right), 27.5\left(\mathrm{C}-3^{\prime \prime}\right), 20.5\left(\mathrm{C}-2^{\prime \prime}\right)$.

\section{2-[2-methyl-5-(propan-2-yl)anilino]-2- oxoethyl 3,4-dihydroxybenzoate (4d)}

Yield, $76 \%$; melting point, $126^{\circ} \mathrm{C}-128^{\circ} \mathrm{C}$; $\mathrm{R}_{\mathrm{f}}=0.48$ (nhexane:ethyl acetate 2:1); FTIR $v_{\max } \mathrm{cm}^{-1}: 3,376(\mathrm{~N}-\mathrm{H})$, 3,171 (O-H), 2,973 (sp2 C-H), 2,905 (sp3 C-H), 1,730 (C=O ester), 1,671 ( $\mathrm{C}=\mathrm{O}$ amide), 1,592 ( $\mathrm{C}=\mathrm{C}$ aromatic), 1,156

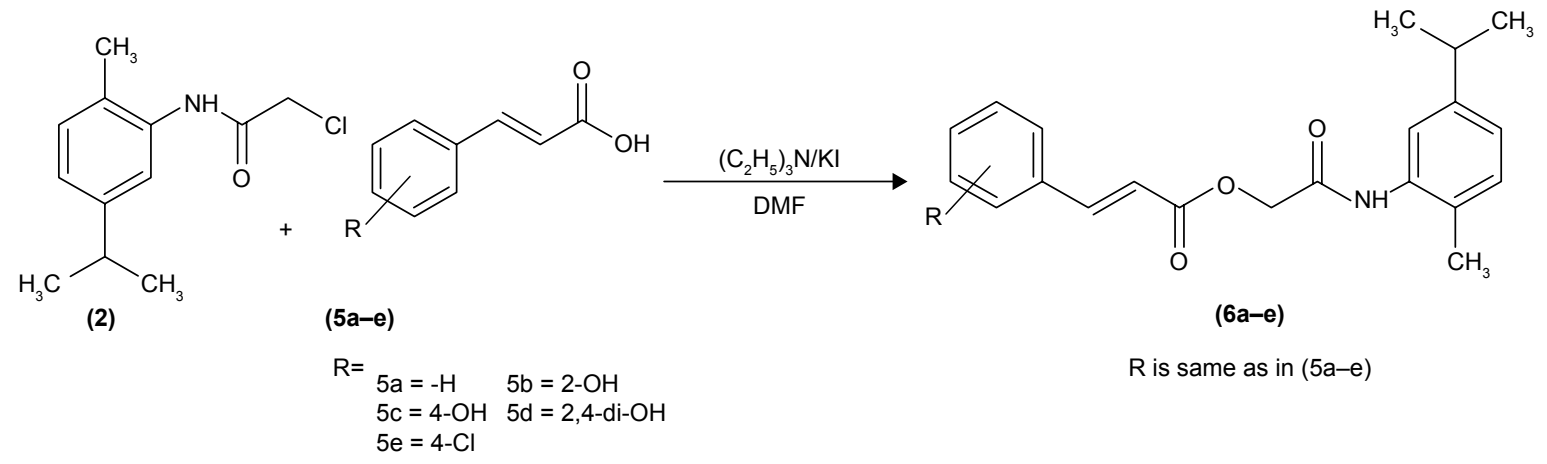

Scheme 2 Synthesis of amide derivatives (6a-e).

Abbreviation: DMF, dimethylformamide. 
(C-O, ester); ${ }^{1} \mathrm{H}$ NMR (DMSO- $d_{6}, \delta$ ppm): 8.45 (s, $\left.1 \mathrm{H},-\mathrm{NH}\right)$, 7.69 (d, $J=2.4 \mathrm{~Hz}, 1 \mathrm{H}, \mathrm{H}-2), 7.52$ (dd, $J=7.6,2.4 \mathrm{~Hz}, 1 \mathrm{H}, \mathrm{H}-6$ ), 7.36 (d, J=7.4 Hz, 1H, H-5), 7.16 (d, $\left.J=1.4 \mathrm{~Hz}, 1 \mathrm{H}, \mathrm{H}-5^{\prime}\right), 6.89$ (d, $J=7.6 \mathrm{~Hz}, 1 \mathrm{H}, \mathrm{H}-3^{\prime}$ ), 6.78 (dd, $J=7.6,1.4 \mathrm{~Hz}, 1 \mathrm{H}, \mathrm{H}-4^{\prime}$ ), 4.96 (s, $2 \mathrm{H},-\mathrm{CH}_{2}$ ), 4.40 (s, $\left.2 \mathrm{H},-\mathrm{OH}\right), 2.80$ (sept, $J=5.8 \mathrm{~Hz}$, 1H, H-1"), 2.19 (s, 3H, H-3"), 1.19 (d, J=5.8 Hz, 6H, H-2"); ${ }^{13} \mathrm{C}$ NMR (DMSO- $d_{6}, \delta$ ppm); $169.6(\mathrm{C}=\mathrm{O}$ ester $), 162.7(\mathrm{C}=\mathrm{O}$ amide), 152.3 (C-3), 146.7 (C-4), 142.5 (C-1'), 138.5 (C-2'), 134.5 (C-5'), 131.9 (C-6), 128.6 (C-4'), 123.7 (C-3'), 122.5 (C-6'), 119.6 (C-2), 116.7 (C-5), 114.8 (C-1), $60.2\left(-\mathrm{CH}_{2}\right)$, 29.5 (C-1"), 24.5 (C-3"), 22.3 (C-2").

\section{2-[2-methyl-5-(propan-2-yl)anilino]-2- oxoethyl 3,5-dihydroxybenzoate (4e)}

Yield, $84 \%$; melting point, $143^{\circ} \mathrm{C}-145^{\circ} \mathrm{C} ; \mathrm{R}_{\mathrm{f}}=0.45$ (nhexane:ethyl acetate 2:1); FTIR $v_{\max } \mathrm{cm}^{-1}: 3,385(\mathrm{~N}-\mathrm{H})$, 3,154 (O-H), 2,954 (sp2 C-H), 2,893 (sp3 C-H), 1,731 ( $\mathrm{C}=\mathrm{O}$ ester), 1,643 ( $\mathrm{C}=\mathrm{O}$ amide), 1,590 ( $\mathrm{C}=\mathrm{C}$ aromatic), 1,160 (C-O, ester); ${ }^{1} \mathrm{H}$ NMR (DMSO- $d_{6}, \delta$ ppm): 8.49 (s, 1H, -NH), 7.33 (d, J=7.4 Hz, 1H, H-3'), 7.19 (d, $J=7.4 \mathrm{~Hz}$, 1H, H-4'), 6.98 (d, J=1.8 Hz, 2H, H-3, H-5), 6.87 (d, $J=1.8$ $\mathrm{Hz}, 1 \mathrm{H}, \mathrm{H}-4), 6.67$ (s, 1H, H-6'), 5.02 (s, 2H, $\left.-\mathrm{CH}_{2}\right), 4.62$ (s, $2 \mathrm{H},-\mathrm{OH}$ ), 2.83 (sept, J=6.2 Hz, 1H, H-1"), 2.20 (s, 3H, H-3"), 1.12 (d, $J=6.2 \mathrm{~Hz}, 6 \mathrm{H}, \mathrm{H}-2$ )); ${ }^{13} \mathrm{C}$ NMR (DMSO- $d_{6}$, $\delta \mathrm{ppm}) ; 169.1$ ( $\mathrm{C}=\mathrm{O}$ ester), 161.2 ( $\mathrm{C}=\mathrm{O}$ amide), 158.3 (C-3, C-5), 155.3 (C-1'), 149.0 (C-2'), 139.1 (C-5'), 133.9 (C-2, C-6), 130.1 (C-4'), 126.3 (C-3'), 123.1 (C-6'), 109.3 (C-4), 108.4 (C-1), $62.7\left(-\mathrm{CH}_{2}\right), 25.5$ (C-1"), 22.6 (C-3"), $19.6\left(\mathrm{C}-2^{\prime \prime}\right)$.

\section{2-[2-methyl-5-(propan-2-yl)anilino]-2-} oxoethyl (2E)-3-phenylprop-2-enoate (6a) Yield, $86 \%$; melting point, $138^{\circ} \mathrm{C}-140^{\circ} \mathrm{C}$; $\mathrm{R}_{\mathrm{f}}=0.62$ (nhexane:ethyl acetate 2:1); FTIR $v_{\max } \mathrm{cm}^{-1}: 3,381(\mathrm{~N}-\mathrm{H})$, 2,951 (sp2 C-H), 2,898 (sp3 C-H), 1,729 (C=O ester), 1,665 $(\mathrm{C}=\mathrm{O}$ amide $), 1,597(\mathrm{C}=\mathrm{C}$ aromatic $), 1,148(\mathrm{C}-\mathrm{O}$, ester); ${ }^{1} \mathrm{H}$ NMR (DMSO- $d_{6}, \delta$ ppm): $8.21(\mathrm{~s}, 1 \mathrm{H},-\mathrm{NH}), 7.62$ (d, $J=16.0 \mathrm{~Hz}, 1 \mathrm{H}, \mathrm{H}-2), 7.48$ (dd, J=7.2, $2.4 \mathrm{~Hz}, 2 \mathrm{H}, \mathrm{H}-2^{\prime}$, H-6'), 7.35-7.39 (m, 3H, H-3', H-4', H-5'), 7.15 (d, J=7.2 Hz, $\left.1 \mathrm{H}, \mathrm{H}-3^{\prime \prime}\right), 7.01$ (d, J=7.2 Hz, 1H, H-4"), 6.91 (s, 1H, H-6"), 6.61 (d, J=16.0 Hz, 1H, H-1), 4.97 (s, 2H, $-\mathrm{CH}_{2}$ ), 2.81 (sept, $J=6.8 \mathrm{~Hz}, 1 \mathrm{H}, \mathrm{H}-1^{\prime \prime \prime}$ ), 2.28 (s, 3H, H-3'"), 1.21 (d, $\left.J=6.8 \mathrm{~Hz}, 6 \mathrm{H}, \mathrm{H}-2^{\prime \prime \prime}\right) ;{ }^{13} \mathrm{C}$ NMR (DMSO- $d_{6}, \delta \mathrm{ppm}$ ); 166.8 (C=O ester), $160.5\left(\mathrm{C}=\mathrm{O}\right.$, amide), $151.3\left(\mathrm{C}-1^{\prime \prime}\right), 140.9$ (C-2), 137.2 (C-2"), 135.3 (C-5"), 130.3 (C-2', C-6'), 128.4 (C-3', C-5'), 124.8 (C-4'), 123.5 (C-1'), 121.2 (C-3"), 119.2 (C-4"), $115.2\left(\mathrm{C}-6^{\prime \prime}\right), 60.5\left(-\mathrm{CH}_{2}\right), 27.8$ (C-1"'), 24.6 (C-3'"'), $19.5\left(\mathrm{C}-2^{\prime \prime \prime}\right)$.

\section{2-[2-methyl-5-(propan-2-yl)anilino]-2- oxoethyl (2E)-3-(2-hydroxyphenyl)prop- 2-enoate (6b)}

Yield, $82 \%$; melting point, $190^{\circ} \mathrm{C}-192^{\circ} \mathrm{C} ; \mathrm{R}_{\mathrm{f}}=0.54$ (n-hexane: ethyl acetate 2:1); FTIR $v_{\text {max }} \mathrm{cm}^{-1}: 3,365(\mathrm{~N}-\mathrm{H}), 3,138(\mathrm{O}-\mathrm{H})$, 2,965 (sp2 C-H), 2,895 (sp3 C-H), 1,738 (C=O ester), 1,673 ( $\mathrm{C}=\mathrm{O}$ amide), 1,595 ( $\mathrm{C}=\mathrm{C}$ aromatic), 1,162 (C-O, ester); ${ }^{1} \mathrm{H}$ NMR (DMSO- $\left.d_{6}, \delta \mathrm{ppm}\right): 8.24(\mathrm{~s}, 1 \mathrm{H},-\mathrm{NH}), 7.83$ (d, J=16.0 Hz, 1H, H-2), 7.62 (d, J=7.6, Hz, 2H, H-6'), 7.58 (dd, J=7.6, 2.2 Hz, 1H, H-4'), 7.42 (dd, $J=7.6,2.4 \mathrm{~Hz}$, 2H, H-5'), 7.38 (d, $J=7.6 \mathrm{~Hz}, 1 \mathrm{H}, \mathrm{H}-3^{\prime}$ ), 7.18 (d, $J=7.4 \mathrm{~Hz}$, 1H, H-3"), 7.09 (d, J=7.4 Hz, 1H, H-4"), 6.91 (s, 1H, H-6"), 6.56 (d, J=16.0 Hz, 1H, H-1), 5.02 (s, 2H, $-\mathrm{CH}_{2}$ ), 3.13 (sept, $J=7.1 \mathrm{~Hz}, 1 \mathrm{H}, \mathrm{H}-1^{\prime \prime \prime}$ ), 2.31 (s, 3H, H-3'"'), 1.21 (d, $\left.J=7.1 \mathrm{~Hz}, 6 \mathrm{H}, \mathrm{H}-2^{\prime \prime \prime}\right) ;{ }^{13} \mathrm{C}$ NMR (DMSO- $d_{6}, \delta \mathrm{ppm}$ ); $165.9(\mathrm{C}=\mathrm{O}$ ester $), 162.2(\mathrm{C}=\mathrm{O}$, amide $), 156.8\left(\mathrm{C}-1^{\prime \prime}\right), 147.2$ (C-2), 141.3 (C-2"), 138.9 (C-5"), 129.4 (C-3', C-5'), 127.3 (C-4'), $125.2\left(\mathrm{C}-1^{\prime}\right), 121.5\left(\mathrm{C}-3^{\prime \prime}\right), 119.4\left(\mathrm{C}-4^{\prime \prime}\right), 114.3\left(\mathrm{C}-2^{\prime}\right.$, C-6'), $111.1\left(\mathrm{C}-6^{\prime \prime}\right), 62.4\left(-\mathrm{CH}_{2}\right), 28.4\left(\mathrm{C}-1^{\prime \prime \prime}\right), 25.4\left(\mathrm{C}-3^{\prime \prime \prime}\right)$, $21.8\left(\mathrm{C}-2^{\prime \prime \prime}\right)$.

\section{2-[2-methyl-5-(propan-2-yl)anilino]-2- oxoethyl (2E)-3-(4-hydroxyphenyl)prop- 2-enoate $(\mathbf{6 c})$}

Yield, 84\%; melting point, $206^{\circ} \mathrm{C}-208^{\circ} \mathrm{C} ; \mathrm{R}_{\mathrm{f}}=0.52(\mathrm{n}-$ hexane:ethyl acetate 2:1); FTIR $v_{\text {max }} \mathrm{cm}^{-1}: 3,363(\mathrm{~N}-\mathrm{H}), 3,193$ (O-H), 2,975 (sp2 C-H), 2,898 (sp3 C-H), 1,725 (C=O ester), 1,652 ( $\mathrm{C}=\mathrm{O}$ amide), 1,596 $(\mathrm{C}=\mathrm{C}$ aromatic $), 1,166$ (C-O, ester); ${ }^{1} \mathrm{H}$ NMR (DMSO- $\left.d_{6}, \delta \mathrm{ppm}\right): 8.78(\mathrm{~s}, 1 \mathrm{H},-\mathrm{NH})$, 7.62 (d, J=16.0 Hz, 1H, H-2), 7.53 (dd, $J=7.4,2.2 \mathrm{~Hz}, 2 \mathrm{H}$, H-2', H-6'), 7.39 (dd, J=7.4, $2.2 \mathrm{~Hz}, 2 \mathrm{H}, \mathrm{H}-3^{\prime}, 5^{\prime}$ ), 7.19 (d, J=7.6 Hz, 1H, H-3"), 7.08 (d, J=7.6 Hz, 1H, H-4"), 6.98 (s, 1H, H-6"), 6.68 (d, J=16.0 Hz, 1H, H-1), 4.99 (s, $2 \mathrm{H},-\mathrm{CH}_{2}$ ), 2.98 (sept, J=6.2 Hz, 1H, H-1'"), 2.31 (s, 3H, $\mathrm{H}-3^{\prime \prime \prime}$ ), 1.21 (d, $J=6.2 \mathrm{~Hz}, 6 \mathrm{H}, \mathrm{H}-2^{\prime \prime \prime}$ ); ${ }^{13} \mathrm{C}$ NMR (DMSO- $d_{6}$, $\delta \mathrm{ppm}) ; 166.3(\mathrm{C}=\mathrm{O}$ ester $), 161.3(\mathrm{C}=\mathrm{O}$, amide $), 156.5$ (C-1"), 142.8 (C-2), 139.5 (C-2"), $136.4\left(\mathrm{C}-5^{\prime \prime}\right), 132.5$ (C-3', C-5'), $130.4\left(\mathrm{C}-4^{\prime}\right), 127.3\left(\mathrm{C}-1^{\prime}\right), 121.6\left(\mathrm{C}-3^{\prime \prime}\right), 119.4\left(\mathrm{C}-4^{\prime \prime}\right)$, 117.5 (C-2', C-6'), 112.7 (C-6"), $62.4\left(-\mathrm{CH}_{2}\right), 28.4\left(\mathrm{C}-1^{\prime \prime \prime}\right)$, 25.5 (C-3'"), 21.4 (C-2'"').

\section{2-[2-methyl-5-(propan-2-yl)anilino]-2- oxoethyl (2E)-3-(2,4-hydroxyphenyl)prop- 2-enoate (6d)}

Yield, $76 \%$; melting point, $224^{\circ} \mathrm{C}-226^{\circ} \mathrm{C}$; $\mathrm{R}_{\mathrm{f}}=0.44$ (nhexane:ethyl acetate 2:1); FTIR $v_{\text {max }} \mathrm{cm}^{-1}: 3,387(\mathrm{~N}-\mathrm{H}), 3,158$ (O-H), 2,958 (sp2 C-H), 2,890 (sp3 C-H), 1,735 (C=O ester), 
1,648 $(\mathrm{C}=\mathrm{O}$ amide $), 1,598(\mathrm{C}=\mathrm{C}$ aromatic $), 1,168(\mathrm{C}-\mathrm{O}$, ester); ${ }^{1} \mathrm{H}$ NMR (DMSO- $d_{6}, \delta$ ppm): $8.89(\mathrm{~s}, 1 \mathrm{H},-\mathrm{NH}), 7.78$ (d, J=16.0 Hz, 1H, H-2), 7.49 (d, J=7.2 Hz, 1H, H-6'), 7.43 (d, J=7.2 Hz, 1H, H-5') 7.39 (s, 1H, H-3'), 7.19 (d, J=7.2 Hz, 1H, H-3"), 7.02 (d, J=6.6 Hz, 1H, H-4"), 6.94 (s, 1H, H-6"), 6.62 (d, J=16.0 Hz, 1H, H-1), 5.01 (s, 2H, $-\mathrm{CH}_{2}$ ), 3.21 (sept, $\left.J=6.8 \mathrm{~Hz}, 1 \mathrm{H}, \mathrm{H}-1^{\prime \prime \prime}\right), 2.35$ (s, 3H, H-3'”), 1.31 (d, $J=7.2 \mathrm{~Hz}$, $\left.6 \mathrm{H}, \mathrm{H}-2^{\prime \prime \prime}\right) ;{ }^{13} \mathrm{C}$ NMR (DMSO- $\left.d_{6}, \delta \mathrm{ppm}\right) ; 166.3$ (C=O ester), 160.2 (C=O, amide), 157.6 (C-1"), 147.9 (C-2), 146.2 (C-2"), 137.5 (C-5"), 130.5 (C-3'), 127.1 (C-5'), 126.4 (C-4'), 127.2 $\left(\mathrm{C}-1^{\prime}\right), 125.5$ (C-3"), 123.2 (C-4"), 121.6 (C-2'), 118.5 $\left(\mathrm{C}-6^{\prime}\right), 112.7\left(\mathrm{C}-6^{\prime \prime}\right), 62.4\left(-\mathrm{CH}_{2}\right), 27.3\left(\mathrm{C}-1^{\prime \prime \prime}\right), 26.3\left(\mathrm{C}-3^{\prime \prime \prime}\right)$, $21.3\left(\mathrm{C}-2^{\prime \prime \prime}\right)$.

\section{2-[2-methyl-5-(propan-2-yl)anilino]-2- oxoethyl (2E)-3-(4-chlorophenyl)prop-2- enoate (6e)}

Yield, $86 \%$; melting point, $139^{\circ} \mathrm{C}-141^{\circ} \mathrm{C}$; $\mathrm{R}_{\mathrm{f}}=0.62$ (nhexane:ethyl acetate $2: 1) ;$ FTIR $v_{\text {max }} \mathrm{cm}^{-1}: 3,365(\mathrm{~N}-\mathrm{H}), 2,967$ (sp2 C-H), 2,898 (sp3 C-H), 1,735 (C=O ester), 1,656 ( $\mathrm{C}=\mathrm{O}$ amide), 1,598 ( $\mathrm{C}=\mathrm{C}$ aromatic), 1,148 (C-O, ester); ${ }^{1} \mathrm{H}$ NMR (DMSO- $d_{6}, \delta$ ppm): 8.24 (s, 1H, -NH), 7.82 (d, $J=16.0 \mathrm{~Hz}$, $1 \mathrm{H}, \mathrm{H}-2), 7.51$ (d, $\left.J=7.6 \mathrm{~Hz}, 2 \mathrm{H}, \mathrm{H}-2^{\prime}, 6^{\prime}\right), 7.36$ (d, $J=7.6 \mathrm{~Hz}$, $1 \mathrm{H}, \mathrm{H}-3^{\prime \prime}$ ), 7.16 (d, J=7.6 Hz, 1H, H-4"), 6.98 (s, 1H, H-6"), 6.77 (d, J=7.6 Hz, 2H, H-3', H-5'), 6.48 (d, J=16.0 Hz, 1H, $\mathrm{H}-1$ ), 5.01 (s, 2H, $-\mathrm{CH}_{2}$ ), 3.11 (sept, $J=5.8 \mathrm{~Hz}, 1 \mathrm{H}, \mathrm{H}-1^{\prime \prime \prime}$ ), 2.48 (s, 3H, H-3'"), 1.19 (d, J=5.8 Hz, 6H, H-2'"); ${ }^{13} \mathrm{C}$ NMR $\left(\mathrm{CDCl}_{3}, \delta \mathrm{ppm}\right) ; 167.6$ (C=O ester), 161.3 (C=O, amide), 153.4 (C-1"), 148.8 (C-2), 137.6 (C-2"), 134.6 (C-5"), 131.8 (C-2', C-6'), 129.5 (C-3', C-5'), 127.9 (C-4'), 124.5 (C-1'), 122.5 (C-3"), 120.4 (C-4"), $118.3\left(\mathrm{C}-6^{\prime \prime}\right), 62.9\left(-\mathrm{CH}_{2}\right), 29.4$ $\left(\mathrm{C}-1^{\prime \prime \prime}\right), 25.6\left(\mathrm{C}-3^{\prime \prime \prime}\right), 22.3\left(\mathrm{C}-2^{\prime \prime \prime}\right)$.

\section{Mushroom tyrosinase inhibition assay}

Mushroom tyrosinase (Sigma-Aldrich, St Louis, MO, USA) inhibition was performed following our previously reported methods. ${ }^{25}$ In detail, $140 \mu \mathrm{L}$ of phosphate buffer $(20 \mathrm{mM}$, $\mathrm{pH} 6.8), 20 \mu \mathrm{L}$ of mushroom tyrosinase $(30 \mathrm{U} / \mathrm{mL})$ and $20 \mu \mathrm{L}$ of the inhibitor solution were placed in the wells of a 96-well microplate. After preincubation for $10 \mathrm{~min}$ at room temperature, $20 \mu \mathrm{L}$ of L-DOPA (3,4-dihydroxyphenylalanine, Sigma-Aldrich) $(0.85 \mathrm{mM})$ was added and the assay plate was further incubated at $25^{\circ} \mathrm{C}$ for $20 \mathrm{~min}$. Afterwards, the absorbance of dopachrome was measured at $475 \mathrm{~nm}$ using a microplate reader (Optimax Max Tunable, Sunnyvale, CA, USA). Kojic acid was used as a reference inhibitor and phosphate buffer was used as a negative control. The extent of inhibition by the test compounds was expressed as the percentage of concentration necessary to achieve 50\% inhibition $\left(\mathrm{IC}_{50}\right)$. Each concentration was analyzed in three independent experiments. $\mathrm{IC}_{50}$ values were determined by data analysis and by a graphing software, Origin 8.6, 64-bit.

Percent inhibition of tyrosinase was calculated using the following equation:

$$
\text { Inhibition }(\%)=\left[\frac{\mathrm{B}-\mathrm{S}}{\mathrm{B}}\right] \times 100
$$

Here, $\mathrm{B}$ and $\mathrm{S}$ are the absorbance of the blank and samples.

\section{Elastase inhibition assay}

Elastase (elastase from porcine pancreas) inhibition assay was performed based on the methods reported by Kraunsoe et $\mathrm{al}^{26}$ and Kim et $\mathrm{al}^{27}$ with a few modifications. In order to perform elastase inhibition assay, the amount of released $p$-nitroaniline, which was hydrolyzed from the substrate (N-succinyl-Ala-Ala-Ala-p-nitroanilide) by elastase, was determined by measuring the absorbance at $410 \mathrm{~nm}$. In detail, $0.8 \mathrm{mM}$ solution of $\mathrm{N}$-succinyl-Ala-Ala-Ala-pnitroanilide was prepared in a $0.2 \mathrm{M}$ Tris- $\mathrm{HCl}$ buffer $(\mathrm{pH}$ $8.0)$ and this buffer $(130 \mu \mathrm{L})$ was added to the test sample $(10 \mu \mathrm{L})$ in a $96-w e l l$ microplate. The microplate was preincubated for $10 \mathrm{~min}$ at $25^{\circ} \mathrm{C}$ before elastase ( 0.0375 unit/ $\mathrm{mL})$ stock solution $(10 \mu \mathrm{L})$ was added. After the addition of the enzyme, the microplate was kept at $25^{\circ} \mathrm{C}$ for $30 \mathrm{~min}$ and the absorbance was measured at $410 \mathrm{~nm}$ using microplate reader. All experiments were carried out in triplicate and elastase inhibitory activity was calculated according to the following formula:

Elastase inhibition activity $(\%)=\frac{\mathrm{OD}_{\text {control }}-\mathrm{OD}_{\text {sample }}}{\mathrm{OD}_{\text {control }}} \times 100$

where $\mathrm{OD}_{\text {control }}$ is the optical density of the control and $\mathrm{OD}_{\text {sample }}$ is the optical density of the sample. Oleanolic acid was used as the standard inhibitor for elastase.

\section{Free radical scavenging assay}

Free radical scavenging activity of amide derivatives was determined based on previously reported methods with few modifications. ${ }^{28,29}$ The assay solution consisted of $100 \mu \mathrm{L}$ of DPPH $(150 \mu \mathrm{M})$ and $20 \mu \mathrm{L}$ of increasing concentration of test compounds, and the volume was adjusted to $200 \mu \mathrm{L}$ in each well with DMSO. The reaction mixture was then incubated 
for $30 \mathrm{~min}$ at room temperature. Ascorbic acid (vitamin C) was used as a reference inhibitor. The assay measurements were carried out using a microplate reader $\left(\mathrm{OPTI}_{\mathrm{Max}}\right.$, Tunable) at $517 \mathrm{~nm}$. The reaction rates were compared and the percent inhibition caused by the presence of tested inhibitors was calculated. Each concentration was analyzed in three independent experiments run in triplicate.

\section{Kinetic analysis of the inhibition of tyrosinase}

A series of experiments was performed to calculate the inhibitory kinetics of compounds $4 \mathbf{c}, \mathbf{6 a}, \mathbf{6 b}$ and $\mathbf{6 d}$ following the previously reported method. ${ }^{30}$ The compounds' concentrations were as follows: $0,3.125,6.25$ and $12.5 \mu \mathrm{M}$ for $\mathbf{4 c} ; 0,0.3915$ and $0.783 \mu \mathrm{M}$ for $\mathbf{6 a} ; 0,0.453,0.965,1.813$ and $3.626 \mu \mathrm{M}$ for $\mathbf{6 b}$; and $0,0.08,0.16$ and $0.32 \mu \mathrm{M}$ for $\mathbf{6 d}$. Substrate L-DOPA concentration was between 0.0625 and $2 \mathrm{mM}$ in all kinetic studies. Preincubation and measurement time was the same as discussed in mushroom tyrosinase inhibition assay protocol. Maximal initial velocity was determined from initial linear portion of absorbance up to 5 min after addition of enzyme at a $30 \mathrm{~s}$ interval. The type of inhibition was determined by using Lineweaver-Burk plots. The enzyme inhibitor (EI) dissociation constant $K i$ was determined by secondary plot of $1 / V$ versus inhibitor concentrations, while enzyme-substrate-inhibitor (ESI)dissociation constant $K i^{\prime}$ was determined by intercept versus inhibitor concentrations. The reversible kinetics of the EI complex was also determined for different concentrations of compound $\mathbf{6 d}$ versus the enzyme concentration $(4,6,8$, $10,15$ and $20 \mu \mathrm{g} / \mathrm{mL})$.

\section{Human tyrosinase inhibition assay \\ Cell culture and preparation of tyrosinase}

A375 human melanoma cells were obtained from American Type Culture Collection (ATCC, Rockville, MD, USA). A375 cells were grown in Dulbecco's Modified Eagle's Medium (Invitrogen, Burlington, ON, Canada) supplemented with L-glutamine, 10\% (v/v) fetal bovine serum (Invitrogen), $50 \mu \mathrm{g} / \mathrm{mL}$ streptomycin (Sigma-Aldrich), 50 units $/ \mathrm{mL}$ penicillin (Sigma-Aldrich) and supplemented with $200 \mu \mathrm{M}$ of L-tyrosine for tyrosinase induction. Cell cultures were incubated at $37^{\circ} \mathrm{C}$, in a humidified atmosphere of $5 \% \mathrm{CO}_{2}$. Cells were scraped out from the tissue culture plate with phosphate-buffered saline (PBS) and were homogenized at $4^{\circ} \mathrm{C}$ in PBS. The homogenate was centrifuged at $1,000 \times g$ for $10 \mathrm{~min}$. The precipitate was sonicated in PBS on ice and the mixture was centrifuged at $10,000 \times \mathrm{g}$ for $30 \mathrm{~min}$.
The supernatant containing tyrosinase was used for the measurement of the inhibitory effects.

\section{Tyrosinase inhibition assay}

The tyrosinase inhibitory activity of the synthesized amides was determined following the previously reported method with few modifications. ${ }^{31,32}$ The assay reaction mixture $(200 \mu \mathrm{L})$ contained $3.3 \mathrm{mM}$ L-DOPA in $0.33 \mathrm{M}$ phosphate buffer ( $\mathrm{pH} 7.0$ ) and the enzyme in the presence and absence of inhibitors. Fifteen or 20 units of tyrosinase was used to determine the $\%$ inhibition. The reaction mixture was incubated at $37^{\circ} \mathrm{C}$ for $10 \mathrm{~min}$ and the absorbance was recorded at $475 \mathrm{~nm}$ using a microplate reader (OPTI Max, Tunable). One unit of enzyme was defined as the amount of enzyme that increases the absorbance value by 0.001 at $475 \mathrm{~nm}$ per minute under the same conditions as described earlier.

\section{In vivo depigmentation assay in zebrafish}

In vivo depigmentation assay was performed in zebrafish according to the previously described method. ${ }^{33}$

\section{Zebrafish husbandry}

Adult wild-type zebrafish (Danio rerio) were purchased from a commercial dealer and were acclimated for 1 month in standard laboratory conditions using a photoperiod of $14 \mathrm{~h}$ light and $10 \mathrm{~h}$ dark at a temperature of $28.5^{\circ} \mathrm{C}$. Fish were fed two times daily with dry food and live brine shrimp larvae. They were kept in thermostatic tanks under constant chemical, biological and mechanical water filtration and aeration. Embryos were obtained from natural spawning that was induced at the morning by turning on the light. Collection of embryos was completed within $30 \mathrm{~min}$. All procedures were performed as described in the "Principles of Laboratory Animal Care" (NIH publication no 85-23, revised 1985), and the study was approved by the Institutional Review Board of Kongju National University (IRB No 2011-2).

\section{Compound treatment and phenotype- based evaluation}

The collected synchronized embryos were arrayed by pipette into a 96-well plate: two to three embryos per well with $200 \mu \mathrm{L}$ of E3 medium ( $\mathrm{NaCl} 5 \mathrm{mM}, \mathrm{KCl} 0.17 \mathrm{mM}$, $\mathrm{CaCl}_{2} 0.33 \mathrm{mM}$ and $\left.\mathrm{MgSO}_{4} 0.33 \mathrm{mM}\right)$. The most potent compound $6 \mathbf{d}$ solution (in $0.1 \%$ DMSO) was added to the E3 medium from 9 to $72 \mathrm{hpf}$ (hours post-fertilization, a total exposure time of $63 \mathrm{~h}$ ). The positive control was treated with kojic acid. Dechorionated embryos were anesthetized in tricaine methanesulfonate MS-222 solution (Sigma-Aldrich), 
mounted in $1 \%$ methyl cellulose on a depression slide and photographs were taken using stereomicroscope (SMZ745T; Nikon, Shinagawa, Japan) for observation. Pixel measurements were carried out using ImageJ software package (National Institutes of Health, Bethesda, MD, USA).

\section{Determination of melanin contents in zebrafish}

Melanin contents in zebrafish were determined following the previously reported method. ${ }^{34,35}$ For melanin contents determination, $50 \mu \mathrm{M}$ dose was selected on the basis of in vivo depigmentation results. The collected synchronized embryos were arrayed by dropper into the dish: $20 \pm 2$ embryos were used in the dish and treated with compound $\mathbf{6 d}$ and $50 \mu \mathrm{M}$ of reference drug kojic acid in $3 \mathrm{~mL}$ of E3 medium. After 72 hpf, embryos were anesthetized in tricaine methanesulfonate MS-222 solution. After anesthetizing, embryos were washed three times with E3 medium and eyes were removed from all the treated and non-treated embryos. Embryos extract (pellet) was prepared by homogenization and centrifugation, and the pellet was dissolved in $1 \mathrm{~mL}$ of $1 \mathrm{~N} \mathrm{NaOH}$ at $100^{\circ} \mathrm{C}$ for $10 \mathrm{~min}$. The level of melanin was measured at an absorbance of $405 \mathrm{~nm}$, and the result was compared with a standard curve of synthetic melanin. All experiments were repeated three times.

\section{Zebrafish toxicity assay}

Zebrafish toxicity assay was performed according to the previously reported method. ${ }^{36}$ Prior to compounds treatment, 48 hpf embryos were enzymatically dechorionated using pronase (protease from Streptomyces griseus, $3 \mathrm{mg} / \mathrm{mL}$; Sigma-Aldrich) for $15 \mathrm{~min}$, then rinsed with E3 medium three times and two to three embryos were dispensed in 96-well plate with $200 \mu \mathrm{L}$ of E3 medium. Embryos were treated with 10,20 and $50 \mu \mathrm{M}$ doses of compounds and pates were maintained at $28^{\circ} \mathrm{C}$ for further $72 \mathrm{~h}$. The survival rate of larvae was assessed at day 5 , and during the experiment no food was provided to larvae. In order to evaluate any extent of apoptotic cellular death, after 3 days of treatment (total 5 days), embryos were stained with $1 \mu \mathrm{g} / \mathrm{mL}$ of acridine orange in E3 medium for $30 \mathrm{~min}$. Excess dye was removed by washing three times with E3 medium. The embryos were anesthetized and photographs were taken as described in section "In vivo depigmentation zebrafish assay".

\section{Computational studies}

\section{Retrieval of protein structure}

The three dimensional (3D) crystal structure of mushroom tyrosinase (Agaricus bisporus) (PDBID: 2Y9X) was retrieved from Protein Data Bank (PDB) (http://www.rcsb.org). The energy minimization of target protein was carried out by employing conjugate gradient algorithm and Amber force field in UCSF Chimera 1.10.1. ${ }^{37}$ Stereochemical properties and Ramachandran graph and values ${ }^{38}$ of mushroom tyrosinase were assessed by Molprobity server, ${ }^{39}$ while the hydrophobicity graph was generated by Discovery Studio 4.1 Client. ${ }^{40}$ The protein architecture and statistical percentage values of helices, beta-sheets, coils and turns were accessed by VADAR $1.8 .^{41}$

\section{Candidate structures}

The synthesized amide derivatives $\mathbf{4 a}-\mathbf{e}$ and $\mathbf{6 a}-\mathbf{e}$ were drawn by $\mathrm{ACD} / \mathrm{ChemSketch}$ tool. The designed ligands were further visualized and minimized by UCSF Chimera 1.10.1. The biochemical properties of these compounds $4 \mathbf{a}-\mathbf{e}$ and 6a-e were predicted by various computational tools such as Molinspiration (http://www.molinspiration.com/) and Molsoft (http://www.molsoft.com/). Lipinski's rule of five (RO5) was justified by Molsoft and Molinspiraion tools.

\section{Molecular docking}

Molecular docking experiment was employed on all synthesized ligands $\mathbf{4 a}-\mathbf{e}$ and $\mathbf{6 a}-\mathbf{e}$ against mushroom tyrosinase using diverse PyRx tool. ${ }^{42}$ The preferred orientation of ligands within the active region of target proteins was determined in docking studies. To run the docking experiment, grid box parametric dimension values were adjusted as $X=61.0781$, $\mathrm{Y}=56.3001$ and $\mathrm{Z}=63.1015$, whereas the centered values were fixed as $\mathrm{X}=-2.9272, \mathrm{Y}=22.0164$ and $\mathrm{Z}=-32.4883$, respectively. The default exhaustiveness value was set as 8 to obtain the finest binding conformational pose of proteinligand docked complexes. All compounds were docked separately against the crystal structure of mushroom tyrosinase. The docked complexes were further evaluated on lowest binding energy (Kcal/mol) values and hydrogen and hydrophobic bond analysis using Discovery Studio (4.1) and UCSF Chimera 1.10.1. 2D graphical depictions of all other compounds were carried out by LIGPLOT. ${ }^{43}$

\section{Molecular dynamics (MD) simulations}

Based on in vitro analysis, docking energies and conformational pose analysis, four best complexes were selected for MD simulation. Groningen Machine for Chemicals Simulations (GROMACS) 4.5.4 package $^{44}$ with GROMOS 53A6 force field was applied on all complexes to interpret the backbone residual flexibility. ${ }^{45}$ The receptor and ligands topology files were created using GROMOS 53A6 force 
field and online PRODRG Server, ${ }^{46}$ respectively. Moreover, the receptor-ligand complexes were solvated and placed in a cubic box center adjusted at a distance of $9 \AA$. Ions were added to neutralize the charge of the system. Energy minimization (nsteps $=50,000$ ) was done by steepest descent method (1,000 ps). Energy calculation was done by Particle Mesh Ewald method, ${ }^{47}$ whereas covalent bond constraints were calculated by linear constraint solver algorithm. ${ }^{48}$ For final MD setup in md.mdp file, time step for integration was adjusted as $0.002 \mathrm{ps}$, while the cut-off distance for short range neighbor list was adjusted as $0.8 \mathrm{~nm}$. The MD run was set to $15,000 \mathrm{ps}$ with nsteps $=750,000$ for each protein-ligand complexes, and trajectories files analysis was done by Xmgrace tool (http://plasma-gate.weizmann. ac.i1/Grace/).

\section{Results and discussion Chemistry}

The title amide analogues $\mathbf{4 a}-\mathbf{e}$ and $\mathbf{6 a}-\mathbf{e}$ were prepared following the previously described method ${ }^{49}$ with slight modification shown in Schemes 1 and 2. The 2-amino- $p$ cymene in the first step is converted into 2-chloro-N-[2methyl-5-(propan-2-yl)phenyl]acetamide (2) by treating with chloroacetyl chloride in the presence of $\left(\mathrm{C}_{2} \mathrm{H}_{5}\right)_{3} \mathrm{~N}$ and anhydrous methylene chloride. The structure of the intermediate $\mathbf{2}$ was ascertained by the presence of amide carbonyl $(-\mathrm{NHC}=\mathrm{O})$ stretching at $1,656 \mathrm{~cm}^{-1}$ and $-\mathrm{NH}$ stretching at $3,354 \mathrm{~cm}^{-1}$ in FTIR spectra. The compounds $\mathbf{4 a}-\mathbf{e}$ and $\mathbf{6 a}-\mathbf{e}$ were synthesized by simple nucleophilic replacement of chloro group from intermediate $\mathbf{2}$ by carboxylic group $(-\mathrm{COOH})$ of substituted benzoic acids $\mathbf{3 a}-\mathbf{e}$ and cinnamic acids $\mathbf{5} \mathbf{a}-\mathbf{e}$, respectively. The structures of the final products were confirmed by FTIR, ${ }^{1} \mathrm{HNMR}$ and ${ }^{13} \mathrm{CNMR}$ spectral data.

\section{In vitro enzymes inhibition assay}

Mushroom tyrosinase and elastase inhibitory activities were determined and it was found that most of the synthesized amides showed better tyrosinase inhibition than standard drug. The hydroxylated amides with cinnamic acid moiety showed higher tyrosinase inhibitory activity than those with benzoic acid residue. The $\mathrm{IC}_{50}$ value of compound $\mathbf{6} \mathbf{d}$ bearing 2,4-dihydroxy substituted cinnamic acid functionality was $0.15 \mu \mathrm{M}$, which explains its excellent tyrosinase inhibitory activity, whereas the $\mathrm{IC}_{50}$ value of standard kojic acid was $17.20 \mu \mathrm{M}$. The same compound (6d) also displayed higher elastase inhibitory potential compared to all other synthesized amide derivatives (Table 1). Bioassay results showed that the
Table I Inhibitory effects of amide derivatives $\mathbf{4 a - e}$ and $\mathbf{6} \mathbf{a}-\mathbf{e}$ on mushroom tyrosinase and porcine pancreas elastase

\begin{tabular}{lll}
\hline Compounds & $\begin{array}{l}\text { Tyrosinase activity } \\
\text { IC }_{50} \pm \text { SEM }(\mu M)\end{array}$ & $\begin{array}{l}\text { Elastase activity } \\
\text { IC }_{50} \pm \text { SEM }(\mu M)\end{array}$ \\
\hline 4a & $10.97 \pm 1.3$ & $41.88 \pm 7.5$ \\
4b & $17.98 \pm 2.5$ & $81.85 \pm 15.2$ \\
4c & $1.80 \pm 0.31$ & $32.93 \pm 9.4$ \\
4d & $10.96 \pm 1.8$ & $24.31 \pm 5.7$ \\
4e & $20.20 \pm 4.9$ & $33.73 \pm 7.2$ \\
6a & $0.78 \pm 0.09$ & $5.01 \pm 1.8$ \\
6b & $1.81 \pm 0.4$ & $13.32 \pm 3.2$ \\
6c & $1.41 \pm 0.1$ & $23.32 \pm 4.2$ \\
6d & $0.15 \pm 0.01$ & $3.73 \pm 0.5$ \\
6e & $16.71 \pm 3.1$ & $35.80 \pm 8.2$ \\
Kojic acid & $17.20 \pm 2.6$ & - \\
Oleanolic acid & - & $1.69 \pm 0.05$ \\
\hline
\end{tabular}

Note: Values are expressed as $I_{50} \pm$ SEM.

Abbreviation: SEM, standard error of mean.

substitution of hydroxyl groups at phenyl ring is the decisive factor of inhibitory activity.

In vitro human tyrosinase inhibition assays showed that compound $\mathbf{6} \mathbf{d}$ exhibited $91.9 \%$ inhibitory capacity at $50 \mu \mathrm{g} / \mathrm{mL}$ (Table 2). This shows that the amide $\mathbf{6 d}$ has a greater potential to inhibit human tyrosinase compared to standard kojic acid (72.9\% inhibitory capacity). Hence, we propose that substitution of hydroxyl group in phenyl ring in case of compound $\mathbf{6 d}$ impedes the molecule to interact well with the active sites of enzyme. The kinetic analysis and docking studies helped us to explore the mode of binding and residual interactions between the enzyme and synthesized inhibitors.

Table $\mathbf{2}$ Inhibitory effects of amide derivatives $\mathbf{4 a - e}$ and $\mathbf{6 a}-\mathbf{e}$ on human tyrosinase (from melanoma cells) free radical scavenging

\begin{tabular}{lll}
\hline Compounds & $\begin{array}{l}\text { Human tyrosinase } \\
\% \text { inhibition }\end{array}$ & $\begin{array}{l}\text { Free radical scavenging } \\
\% \text { inhibition }\end{array}$ \\
\hline 4a & $61.25 \pm 3.9$ & $25.23 \pm 1.0$ \\
4b & $53.83 \pm 5.3$ & $1.70 \pm 0.5$ \\
4c & $66.67 \pm 6.4$ & $2.4 \pm 0.6$ \\
4d & $56.85 \pm 6.5$ & $91.78 \pm 2.0$ \\
4e & $54.62 \pm 5.8$ & $7.12 \pm 0.8$ \\
6a & $82.35 \pm 8.5$ & $1.39 \pm 0.5$ \\
6b & $53.70 \pm 4.2$ & $1.15 \pm 0.4$ \\
6c & $55.83 \pm 5.7$ & $8.51 \pm 1.0$ \\
6d & $91.87 \pm 8.43$ & $23.51 \pm 2.0$ \\
6e & $57.40 \pm 4.92$ & $7.50 \pm 1.0$ \\
Kojic acid & $72.94 \pm 5.92$ & - \\
Oleanolic acid & - & $95.60 \pm 1.0$ \\
\hline
\end{tabular}

Notes: For human tyrosinase, the concentration of all inhibitors and kojic acid was $50 \mu \mathrm{g} / \mathrm{mL}$, and for free radical scavenging, the concentration of all inhibitors and vitamin $C$ was $100 \mu \mathrm{g} / \mathrm{mL}$. Values are expressed as mean \pm standard error of mean. 


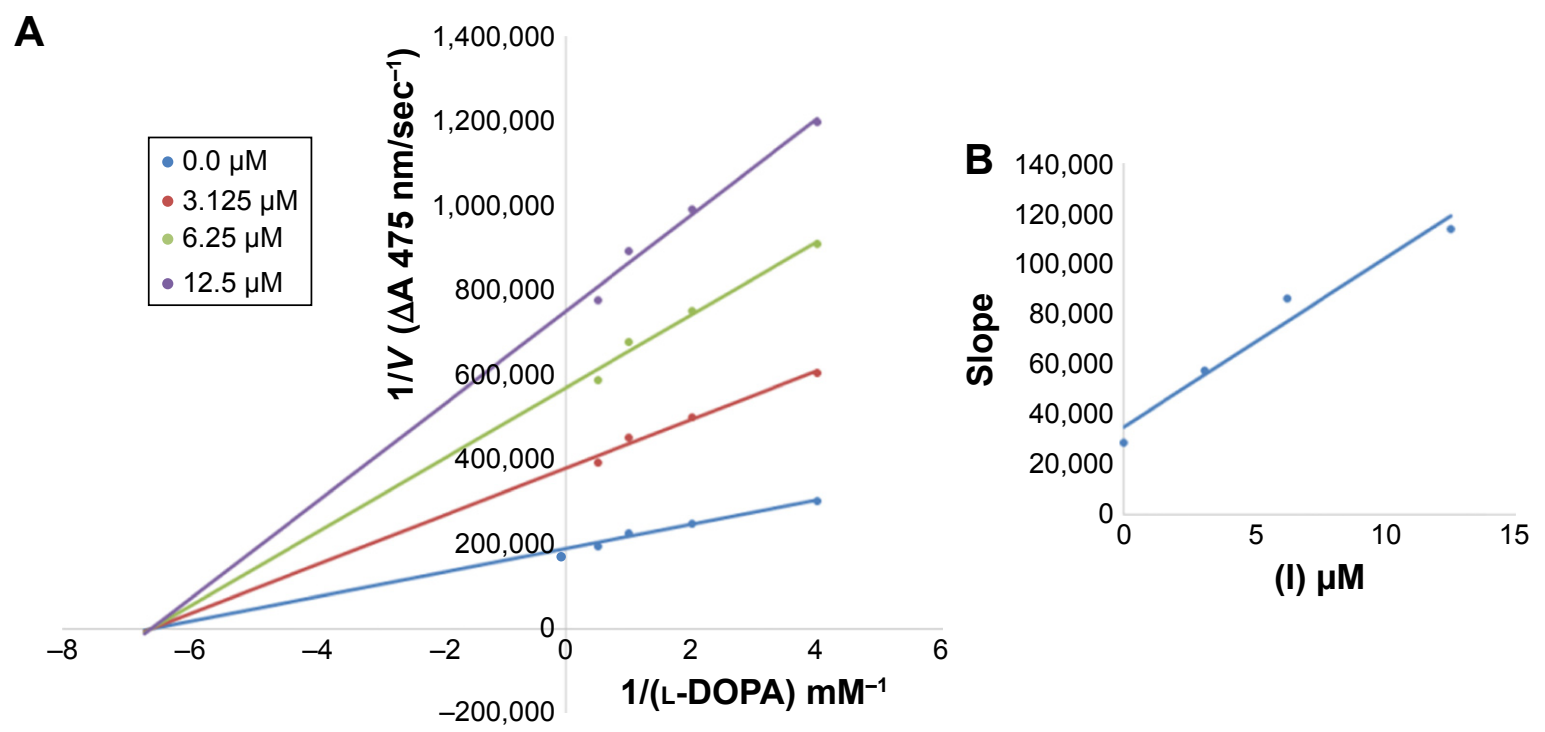

Figure I Lineweaver-Burk plots for inhibition of tyrosinase in the presence of amide $4 \mathbf{c}$.

Notes: (A) Concentrations of $4 \mathbf{c}$ were $0,3.125,6.25$ and $12.5 \mu \mathrm{M}$ and that of substrate L-DOPA were $0.125,0.25,0.5,1$ and $2 \mathrm{mM}$. (B) The plot of the slope. The lines were drawn using linear least squares fit.

\section{Kinetic mechanism}

Among the synthesized amide derivatives, $4 \mathbf{c}, \mathbf{6 a}, \mathbf{6 b}$ and 6d were selected to determine their inhibition type and inhibition constants on mushroom tyrosinase. The potential of these derivatives to inhibit the free enzyme and enzymesubstrate complex was determined in terms of EI and ESI constants, respectively. The kinetic studies of the enzyme by Lineweaver-Burk plot of $1 / V$ versus $1 /[\mathrm{L}-\mathrm{DOPA}]$ in the presence of different inhibitors concentrations gave a series of straight lines as shown in Figures 1-4A. Figures 2A and $3 \mathrm{~A}$ show that compounds $\mathbf{6 a}$ and $\mathbf{6 b}$ intersected within the second quadrant. The analysis showed that $V_{\max }$ decreased with increasing $K_{\mathrm{m}}$ in the presence of increasing concentrations of compounds $\mathbf{6 a}$ and $\mathbf{6 b}$, respectively. This behavior
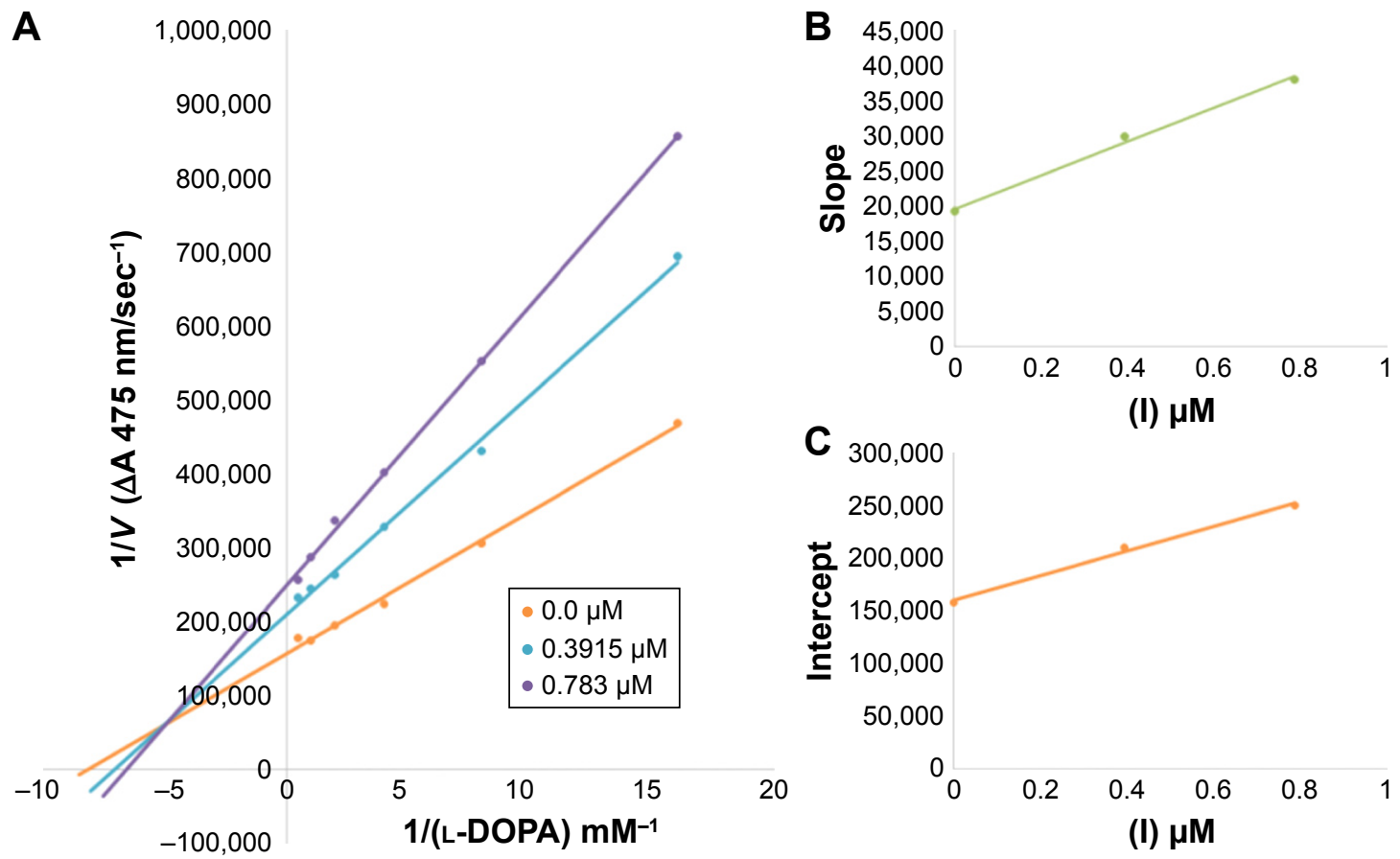

Figure 2 Lineweaver-Burk plots for inhibition of tyrosinase in the presence of amide $\mathbf{6 a}$.

Notes: (A) Concentrations of $\mathbf{6 a}$ were $0,0.3915$, and $0.783 \mu \mathrm{M}$ and those of substrate L-DOPA were $0.125,0.25,0.5, \mathrm{I}$ and $2 \mathrm{mM}$. (B) The plot of the slope and (C) of the vertical intercepts versus inhibitor $\mathbf{6} \mathbf{a}$ concentrations to determine inhibition constants. The lines were drawn using linear least squares fit. 

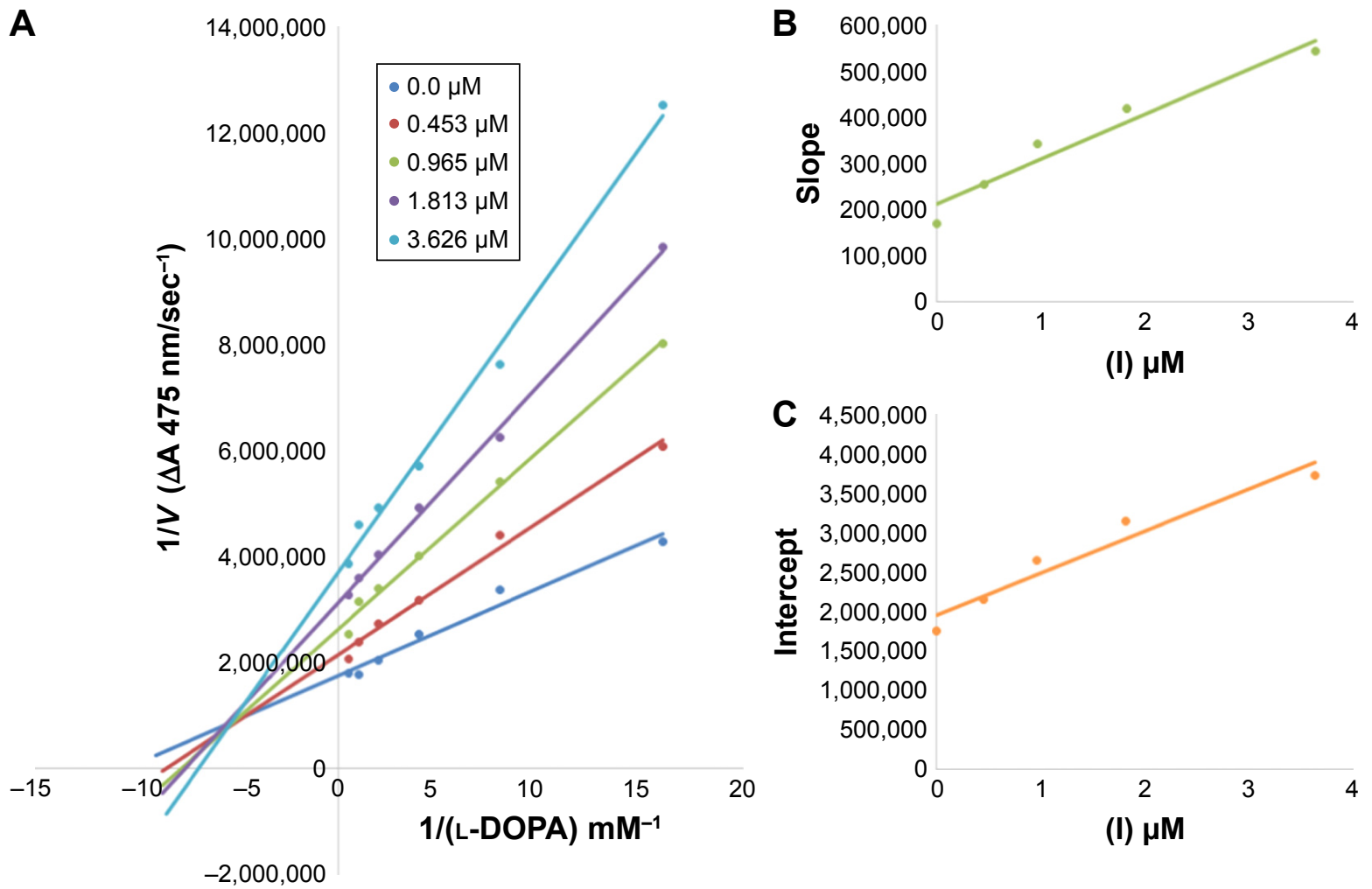

Figure 3 Lineweaver-Burk plots for inhibition of tyrosinase in the presence of amide $\mathbf{6} \mathbf{b}$

Notes: (A) Concentrations of $\mathbf{6 b}$ were $0,0.453,0.965, \mathrm{I} .8 \mathrm{I} 3$ and $3.626 \mu \mathrm{M}$ and those of substrate L-DOPA were $0.125,0.25,0.5, \mathrm{I}$ and $2 \mathrm{mM}$. (B) The plot of the slope and (C) of the vertical intercepts versus inhibitor $\mathbf{6 b}$ concentrations to determine inhibition constants. The lines were drawn using linear least squares fit.

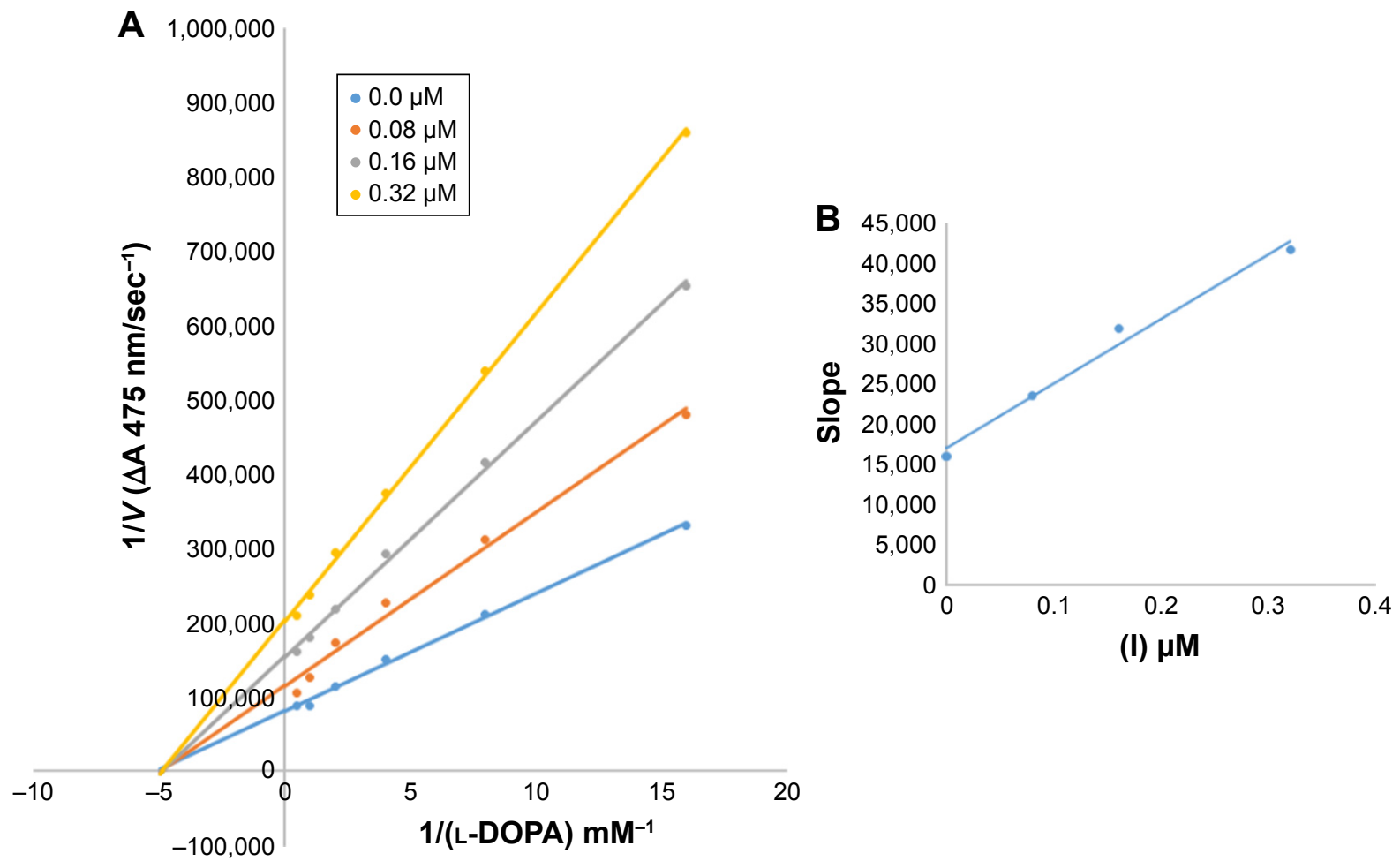

Figure 4 Lineweaver-Burk plots for inhibition of tyrosinase in the presence of amide $\mathbf{6 d}$

Notes: (A) Concentrations of $\mathbf{6 d}$ were $0,0.08,0.16$ and $0.32 \mu \mathrm{M}$ and those of substrate L-DOPA concentrations were $0.125,0.25,0.5,1$ and $2 \mathrm{mM}$. (B) The plot of the slope. The lines were drawn using linear least squares fit. 
Table 3 Kinetic parameters of mushroom tyrosinase for L-DOPA activity in the presence of different concentration of compounds $4 c$, 6a, 6b and 6d

\begin{tabular}{|c|c|c|c|c|c|c|c|}
\hline Code & Dose $(\mu M)$ & $V_{\max }(\Delta A / s e c)$ & $K_{m}(m M)$ & Inhibition type & Inhibition & $K i(\mu \mathrm{M})$ & $K i^{\prime}(\mu \mathrm{M})$ \\
\hline \multirow[t]{4}{*}{$4 c$} & 0.0 & $5.090 \times 10^{-6}$ & 0.138 & Non-competitive & - & 0.188 & - \\
\hline & 3.125 & $2.545 \times 10^{-6}$ & 0.138 & & & & \\
\hline & 6.25 & $1.696 \times 10^{-6}$ & 0.138 & & & & \\
\hline & 12.5 & $1.288 \times 10^{-6}$ & 0.138 & & & & \\
\hline \multirow[t]{3}{*}{$6 a$} & 0.0 & $5.621 \times 10^{-6}$ & 0.112 & Mixed inhibition & - & 0.84 & 1.4 \\
\hline & 0.3915 & $4.294 \times 10^{-6}$ & 0.126 & & & & \\
\hline & 0.783 & $3.909 \times 10^{-6}$ & 0.136 & & & & \\
\hline \multirow[t]{5}{*}{ 6b } & 0.0 & $5.555 \times 10^{-7}$ & 0.089 & Mixed inhibition & - & 2.2 & 3.8 \\
\hline & 0.453 & $4.819 \times 10^{-7}$ & 0.108 & & & & \\
\hline & 0.965 & $3.947 \times 10^{-7}$ & 0.119 & & & & \\
\hline & 1.813 & $3.067 \times 10^{-7}$ & 0.123 & & & & \\
\hline & 3.626 & $2.592 \times 10^{-7}$ & 0.131 & & & & \\
\hline \multirow[t]{4}{*}{$6 d$} & 0.0 & $1.161 \times 10^{-5}$ & 0.217 & Non-competitive & Irreversible & 0.217 & - \\
\hline & 0.08 & $9.598 \times 10^{-6}$ & 0.217 & & & & \\
\hline & 0.16 & $6.233 \times 10^{-6}$ & 0.217 & & & & \\
\hline & 0.32 & $4.787 \times 10^{-6}$ & 0.217 & & & & \\
\hline
\end{tabular}

of compounds $\mathbf{6 a}$ and $\mathbf{6 b}$ indicated that it inhibits tyrosinase by two different pathways: competitively forming EI complex and non-competitively interrupting ESI complex. The EI dissociation constants $K i$ (Figures 2B and 4B) of compounds $\mathbf{6 a}$ and $\mathbf{6 b}$ are shown by the secondary plots of slope versus concentration of compounds, whereas the ESI dissociation constants $K i^{\prime}$ are shown by the secondary plots of intercept versus concentration of compounds (Figures $2 \mathrm{C}$ and $3 \mathrm{C}$ ). A lower value of $K i$ than $K i^{\prime}$ pointed out stronger binding between enzyme and compounds $\mathbf{6 a}$ and $\mathbf{6 b}$, which suggested preferred competitive over non-competitive manners (Table 3).

In case of compounds $\mathbf{4} \mathbf{c}$ and $\mathbf{6} \mathbf{d}$, Lineweaver-Burk plot gave a family of straight lines, all of which intersected at the same point on the $\mathrm{x}$-axis (Figures $1 \mathrm{~A}$ and 4A). The analysis showed that $1 / V_{\max }$ increased to a new value but $K_{\mathrm{m}}$ remained the same as a result of increase in the concentrations of compounds $\mathbf{4 c}$ and $\mathbf{6 d}$. This behavior indicates that compounds $\mathbf{4} \mathbf{c}$ and $\mathbf{6 d}$ inhibit tyrosinase non-competitively to form EI complex. Secondary plot of slope against concentration of $\mathbf{4} \mathbf{c}$ and $\mathbf{6} \mathbf{d}$ shows the EI dissociation constant (Ki) (Figures 1B and 4B). The inhibitory mechanism of mushroom tyrosinase by compounds $\mathbf{6} \mathbf{d}$ at different concentrations $(0.0,0.08,0.16$ and $0.32 \mu \mathrm{M})$ was investigated. The plots of the remaining enzyme activity versus the concentration of enzyme $(4,6,8,10$, 15 and $20 \mu \mathrm{g} / \mathrm{mL}$ ) at different inhibitor concentrations for the catalysis of L-DOPA gave a series of parallel straight lines with the same slopes indicating that the inhibitory effect of $\mathbf{6 d}$ on tyrosinase was irreversible (Figure 5). These results suggest that the compound $\mathbf{6 d}$ effectively inhibited the enzyme by binding to its binuclear active site irreversibly. ${ }^{50}$

\section{In vivo depigmentation assay in zebrafish}

Zebrafish is a very important vertebrate animal model because it possesses similar gene sequence system to human. ${ }^{51}$ Zebrafish embryos were used to determine the depigmentation activity of compound $\mathbf{6 d}$ through in vivo assay. The inhibitory

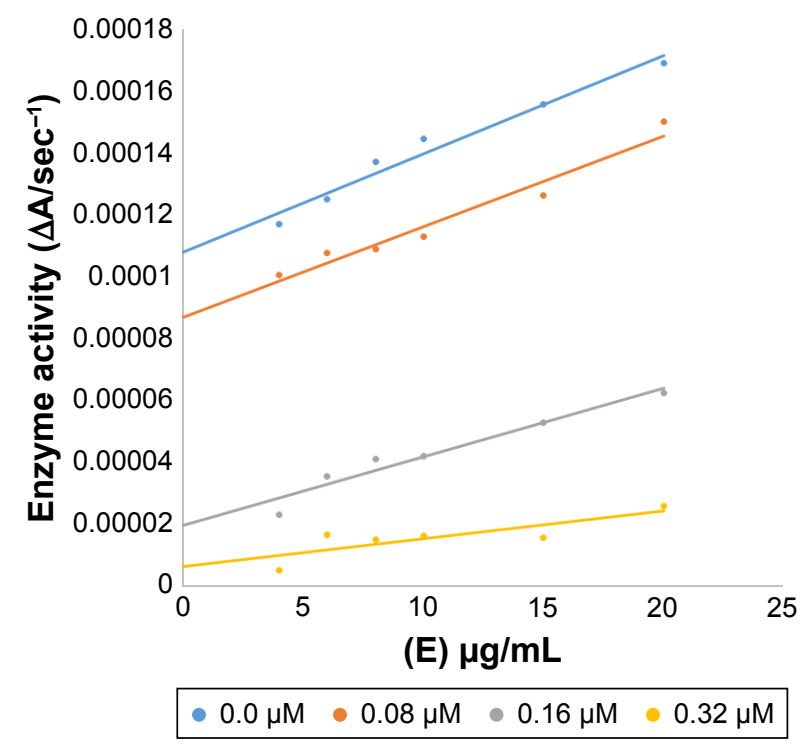

Figure 5 Effect of various doses of mushroom tyrosinase on its activity for the catalysis of L-DOPA against different concentration of inhibitor $\mathbf{6 d}$. 
A Control $5 \mu \mathrm{M} \quad 10 \mu \mathrm{M} 20 \mu \mathrm{M} 50 \mu \mathrm{M}$
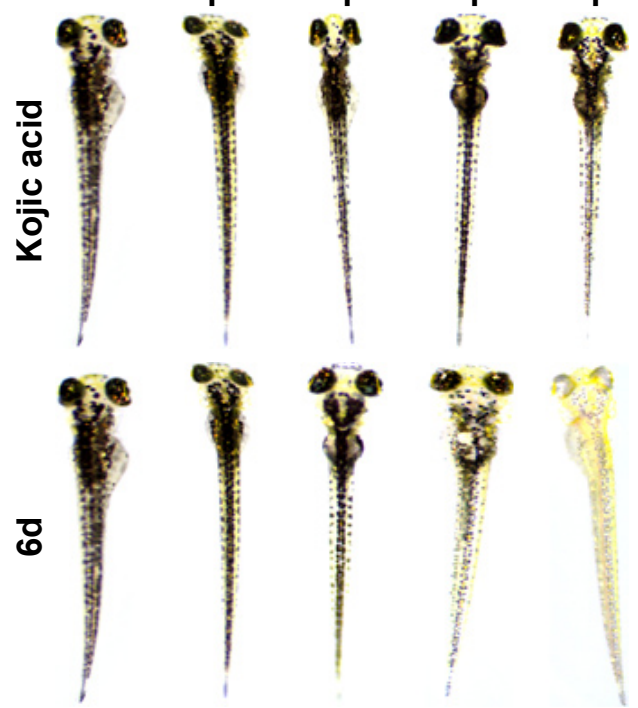

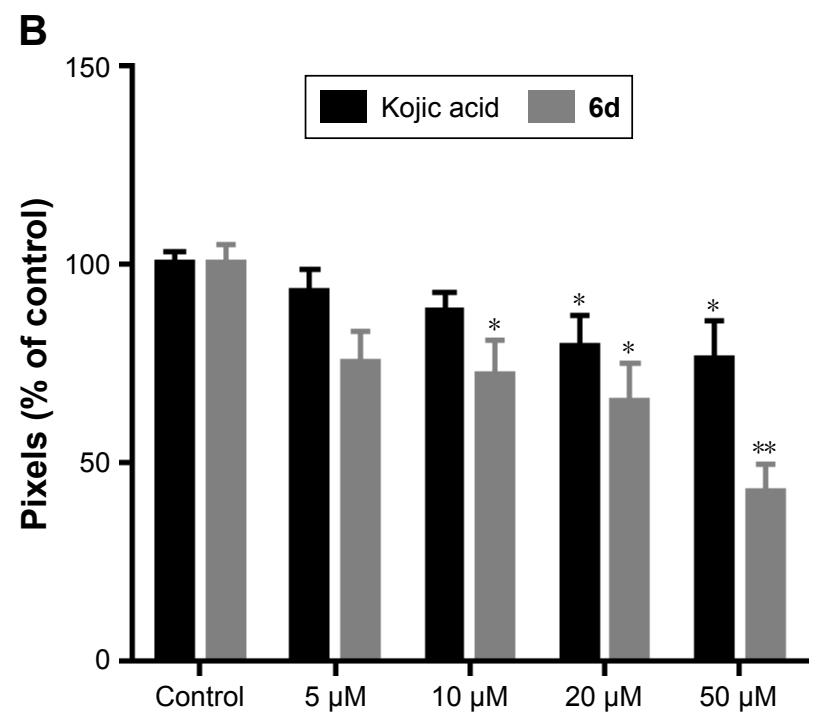

Figure 6 Effect of inhibitor 6d on pigmentation of zebrafish.

Notes: Embryos were treated with 5, I0, 20 and $50 \mu \mathrm{M}$ of $\mathbf{6 d}$ and positive control kojic acid. (A) Representation of the pigmentation levels of zebrafish treated with inhibitor 6d and kojic acid. (B) Pixels comparison of the depigmenting potency of $\mathbf{6 d}$ and kojic acid. $* P<0.05 ; * * P<0.01$.

effects of $\mathbf{6} \mathbf{d}$ on the pigmentation of zebrafish were evaluated by adding $\mathbf{6 d}$ at concentrations of 5, 10, 20 and $50 \mu \mathrm{M}$ to the embryos, and same concentrations were used for positive control kojic acid. Compound 6d significantly decreased $(P<0.05$, Figure 6$)$ the pigmentation level to about $57.3 \%$, while positive control kojic acid decreased the pigmentation level to $24.2 \%$ at $50 \mu \mathrm{M}$. Moreover, inhibitor $\mathbf{6 d}$ showed better depigmenting effects than kojic acid at 10 and $20 \mu \mathrm{M}$.

\section{Determination of melanin contents} in zebrafish

Melanin contents were measured using the extract of zebrafish embryos. Results showed that melanin contents significantly $(P<0.001)$ decreased in the $\mathbf{6 d - t r e a t e d ~ z e b r a f i s h ~}$ embryos at $50 \mu \mathrm{M}$ compared to non-treated embryos and reference drug. Kojic acid only slightly reduced the melanin contents in zebrafish embryos, whereas $\mathbf{6 d}$ highly reduced the melanin contents (Figure 7).

\section{Zebrafish toxicity assay}

In addition to the depigmenting capacity, other factors are also important in selecting the lead compound for skin whitening and related disorders. For that purpose, additional in vivo zebrafish toxicity was also performed. In recent years, zebrafish has emerged as an important tool for early screening of toxicity of drugs. Acute toxicity is determined by treating the larvae after $48 \mathrm{hpf}$ with 10, 20 and $50 \mu \mathrm{M}$ of inhibitor $\mathbf{6 d}$, and fish were examined after 3 days of treatment by staining with acridine orange (Figure 8). The larvae developed into zebrafish normally without any evidence of apoptotic deformities. This absence of acute toxicity was encouraging for safer drug development. Importantly, no death was recorded in any treatment.

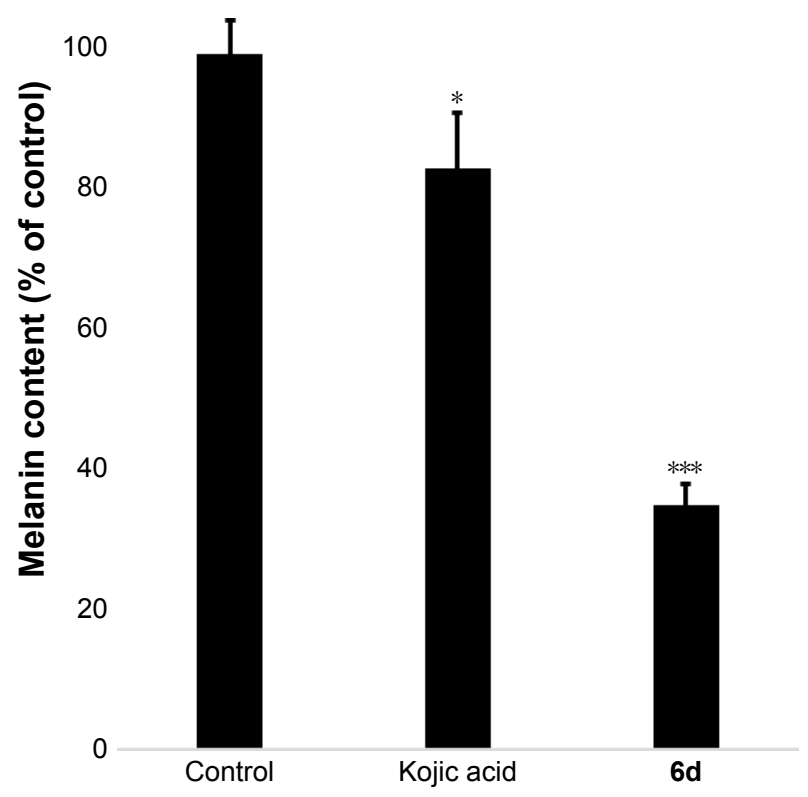

Figure $\mathbf{7}$ Inhibitory effects of $\mathbf{6} \mathbf{d}$ and kojic acid on melanin contents.

Notes: Zebrafish embryos were treated with $50 \mu \mathrm{M}$ of $\mathbf{6 d}$ and kojic acid. After homogenation and centrifugation, pellets were prepared and dissolved with I $\mathrm{N}$ $\mathrm{NaOH}$ at $100^{\circ} \mathrm{C}$, and absorbances were recodred at $405 \mathrm{~nm}$ and compared with synthetic melanin. Values are expressed as $\%$ of control. $* P<0.05$; $* * * P<0.001$. 


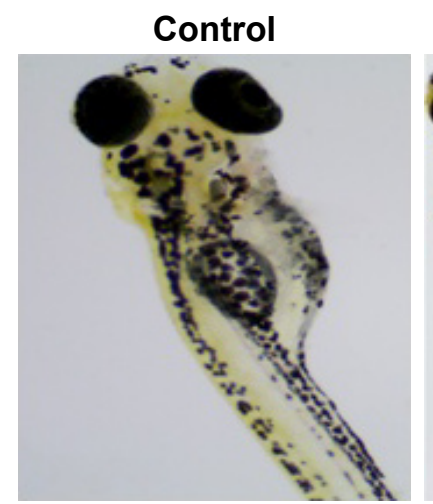

$20 \mu \mathrm{M} 6 \mathrm{~d}$
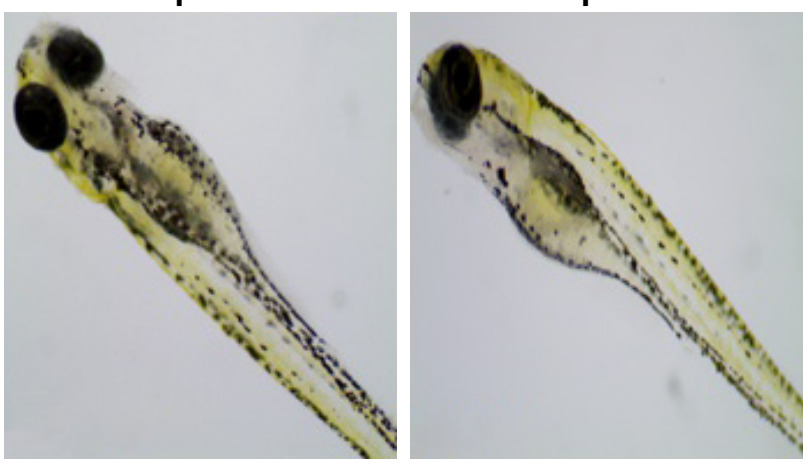

Figure 8 Zebrafish embryos (48 hpf) were treated with 10, 20 and $50 \mu \mathrm{M}$ of $\mathbf{6 d}$. Notes: Normal development was observed after acridine orange staining. Some key features were labeled for reference. a, eyes; b, otic capsule; c, heart; d, yolk; e, melanocytes.

Abbreviation: hpf, hours post-fertilization.

\section{Computational studies}

\section{Structural assessment of target protein}

Mushroom tyrosinase is a class of oxidoreductase coppercontaining protein that comprises 391 amino acids. The structure architecture of mushroom tyrosinase showed that it consists of $39 \% \alpha$-helices (154 residues), $14 \% \beta$-sheets (57 residues) and $46 \%$ coils (180 residues). The crystal structure showed its resolution $2.78 \AA$, R-value 0.238 and unit cell crystal dimensions such as length and angles of coordinates. The unit cell length values were observed for $\mathrm{a}=103.84, \mathrm{~b}=104.82$ and $\mathrm{c}=119.36$ with angles $90^{\circ}$, $110.45^{\circ}$ and $90^{\circ}$ for all $\alpha, \beta$ and $\gamma$ dimensions, respectively. The Ramachandran plots and values indicated that $95.9 \%$ of protein residues were present in favored region and $100.0 \%$ residues were lie in allowed region. The Ramachandran graph values showed a good accuracy of phi $(\phi)$ and psi $(\psi)$ angles among the coordinates of receptor, and most of residues were plunged in acceptable region.

\section{Chemo-informatics properties and Lipinski's RO5}

The predicted chemo-informatics properties such as molecular weight $(\mathrm{g} / \mathrm{mol})$, molar volume $\left(\mathrm{A}^{3}\right)$ and polar surface area (PSA) were evaluated by computational tools. The literature study established a standard value for molecular weight $(160-480 \mathrm{~g} / \mathrm{mol})$ and PSA (x). ${ }^{52}$ Results showed that all the predicted values of synthesized compounds $4 \mathbf{a}-\mathbf{e}$ and 6a-e were comparable with standard values. The obtained drug score is very important for various properties such as physicochemical, pharmacokinetics and pharmacodynamics of chemical compound. Higher drug scores mean good drug characteristics. ${ }^{53}$ The drug scores obtained emphasize that all the synthesized amides $4 \mathbf{4}-\mathbf{e}$ and $\mathbf{6 a}-\mathbf{e}$ exhibited druglike behavior. The highest and lowest drug scores of both $\mathbf{4 c}$ and 6a are 1.41 and 0.35, respectively. Moreover, RO5 did not explain anything about the specific chemistry or structural features of the drugs or non-drugs. The computational results showed that all the synthesized compounds possessed $<10 \mathrm{HBA},<5 \mathrm{HBD}$ and $<5.0 \log P$-values, which significantly justified its drug-like behavior. Moreover, their molecular weight was also $<500 \mathrm{~g} / \mathrm{mol}$, which also justified the compounds' better drug-like behavior. Rule of 5 indicates that molecules with poor absorption are more likely to have more than $5 \mathrm{HBD}$, MWT over 500, $\log P$ over 5 and more than 10 HBA. However, there are plenty of examples that explain RO5 violation among the existing drugs. ${ }^{54}$ In summary, the values obtained justify the significance of the synthesized compounds as good candidate molecules (Table 4).

\section{Molecular docking analyses}

The docked complexes of all amide derivatives $4 \mathbf{a}-\mathbf{e}$ and $\mathbf{6 a}-\mathbf{e}$ were analyzed on the basis of lowest binding energy values (kcal/mol) and hydrogen/hydrophobic bonding analyses. Results showed that $\mathbf{6 d}$ was the most active compound with best binding energy value $(-7.90 \mathrm{kcal} / \mathrm{mol})$ compared to other derivatives. The docking pose was selected on the basis of energy value and interaction patterns of ligand within the active region of the target protein. The conformational position within the active region of the target protein was

Table 4 Chemo-informatics evaluation of the synthesized compounds

\begin{tabular}{lllllllllll}
\hline Properties & $\mathbf{4 a}$ & $\mathbf{4 b}$ & $\mathbf{4 c}$ & $\mathbf{4 d}$ & $\mathbf{4 e}$ & $\mathbf{6 a}$ & $\mathbf{6 b}$ & $\mathbf{6 c}$ & $\mathbf{6 d}$ & $\mathbf{6 e}$ \\
\hline MW & 327 & 327 & 343 & 343 & 343 & 337 & 353 & 353 & 369 & $37 \mathrm{I}$ \\
HBA & 4 & 4 & 5 & 5 & 5 & 3 & 4 & 4 & 5 & 3 \\
HBD & 2 & 2 & 3 & 3 & 3 & $\mathrm{I}$ & 2 & 2 & 3 & $\mathrm{I}$ \\
Log P & 2.8 & 3.8 & 3.4 & 3.4 & 3.5 & 4.8 & 4.4 & 4.5 & 4.1 & 4.5 \\
PSA & $6 \mathrm{I}$ & $6 \mathrm{I}$ & 77 & 76 & 78 & 42 & 59 & 60 & 77 & 42 \\
MV & 328 & 328 & 339 & $34 \mathrm{I}$ & 339 & $36 \mathrm{I}$ & 372 & 372 & 382 & 378 \\
Drug score & $\mathrm{I} .09$ & $\mathrm{I} . \mathrm{II}$ & $\mathrm{I} .4 \mathrm{I}$ & $\mathrm{I} .30$ & 0.85 & 0.35 & 0.42 & 0.68 & 0.69 & 0.83 \\
RO5 & Yes & Yes & Yes & Yes & Yes & Yes & Yes & Yes & Yes & Yes \\
\hline
\end{tabular}

Abbreviations: $\mathrm{MW}$, molecular weight $(\mathrm{g} / \mathrm{mol})$; HBA, hydrogen bond acceptor; HBD, hydrogen bond donor; Log $P$, lipophilicity of partition coefficient; PSA, polar surface area; $M V$, molar volume $\left(A^{3}\right)$; RO5, rule of five. 
confirmed by superimposition. The docked complex of $\mathbf{6 d}$ was superimposed against the experimental crystal structure of tyrosinase. Results showed that the ligand $\mathbf{6 d}$ actively bound within the binding pocket of the target protein. The docking energy values of all the docking complexes were calculated by the following equation:

$$
\begin{aligned}
\Delta \mathrm{G} \text { binding }= & \Delta \mathrm{Ggauss}+\Delta \mathrm{Grepulsion}+\Delta \mathrm{G} \text { hbond } \\
& +\Delta \mathrm{Ghydrophobic}+\Delta \mathrm{G} \text { tors }
\end{aligned}
$$

where,

$\Delta$ Ggauss: attractive term for the dispersion of two Gaussian functions,

$\Delta$ Grepulsion: square of the distance if closer than a threshold value,

$\Delta \mathrm{Ghbond}$ : ramp function - also used for interactions with metal ions,

$\Delta$ Ghydrophobic: ramp function,

$\Delta$ Gtors: proportional to the number of rotatable bonds.

Docking results justified that the synthesized amides $\mathbf{6 b}$, 6d and 6e exhibited good binding energy values (-8.0, -7.9 and $-7.9 \mathrm{kcal} / \mathrm{mol}$, respectively). The standard error for Autodock is reported as $2.5 \mathrm{kcal} / \mathrm{mol}$. Though the basic nucleus of all the synthesized compounds was the same, most of the ligands possessed efficient energy values and did not show any significant difference in energy fluctuations. The comparative binding energies of all the docking complexes are presented in Figure 9.

$-9$

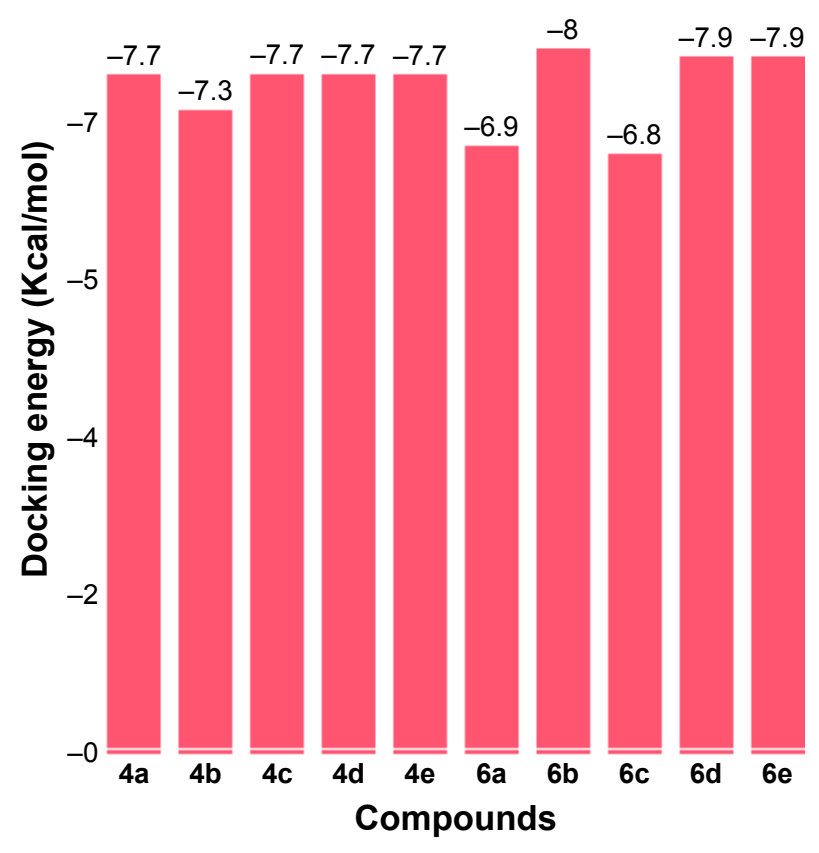

Figure 9 Docking energies of the synthesized amide derivatives $4 \mathbf{a}-\mathbf{e}$ and $\mathbf{6 a}-\mathbf{e}$ calculated using PyRx.
This comparative analysis shows that $\mathbf{6} \mathbf{d}$ directly interacts with the active residues of the target protein. The structureactivity relationship analysis showed that $\mathbf{6 d}$ formed two hydrogen bonds and one $\pi-\pi$ interaction at specific residues His244, Met280 and His363 of target protein. The ester carbonyl oxygen in 6d interacts with His244, while benzyl oxygen moiety interacts with Met280 and forms strong hydrogen bonds with lengths of $1.98 \AA$ and $2.87 \AA$, respectively. Another $\pi-\pi$ interaction between the benzene and metal-bonded His363 residue was formed with a bond length of $4.07 \AA$. The literature study also justified that these interacted residues are significant in the downstream signaling pathways. ${ }^{55}$ The binding interactions of $\mathbf{6 d}$ with the amino acids of the target protein are presented in Figure 10, and the 2D-generated docking complexes of all ligands are presented in Figures S3-S11.

\section{MD simulations analyses}

\section{Root mean square deviation and fluctuations of target protein}

To evaluate the mushroom tyrosinase flexibility and overall stability of docking complexes, we executed time-dependent MD simulation at $15 \mathrm{~ns}$ using Gromacs 4.5.4. The residual deviations and fluctuation of the complexes $\mathbf{6 a}$ and $\mathbf{6} \mathbf{d}$ were determined by root mean square deviation and fluctuation (RMSD/F) graphs generated by Xmgrace software. Both docked complexes were run separately in simulation to check the fluctuating differences of the residual backbone of the target protein. An increasing trend was observed in the graph lines of both complexes with an RMSD value of $0-0.2 \mathrm{~nm}$ at time $0-1,250 \mathrm{ps}$, after which both complexes showed slight fluctuations and attained a little stability from 1,250 to $5,000 \mathrm{ps}$ with a constant RMSD value of $0.2 \mathrm{~nm}$. From 5,000 to 75,000 ps, 6d graph line remained steadily constant and showed no fluctuations, whereas 6a graph line showed an increasing trend and depicted higher RMSD value of $0.25 \mathrm{~nm}$. Comparative analysis showed that $\mathbf{6 d}$ had more stable behavior compared to 6a complex. These results justified that the binding of $\mathbf{6} \mathbf{d}$ toward the target protein is more stable compared to all other 6a derivative (Figure 11).

The overall RMSD results justified that $\mathbf{6 d}$ did not change the conformational symmetry of the target protein compared to 6a. The RMSF results also reflected that both $\mathrm{C}$ - and $\mathrm{N}$-terminal lobes of mushroom tyrosinase are fluctuated throughout the simulation period. Comparative analysis justified that $\mathbf{6 d}$ is more stable and less fluctuated throughout the simulation period compared to $\mathbf{6 a}$ (Figure 12). MD simulation graphs showed stable behaviors of $\mathbf{6} \mathbf{d}$ docked complex 


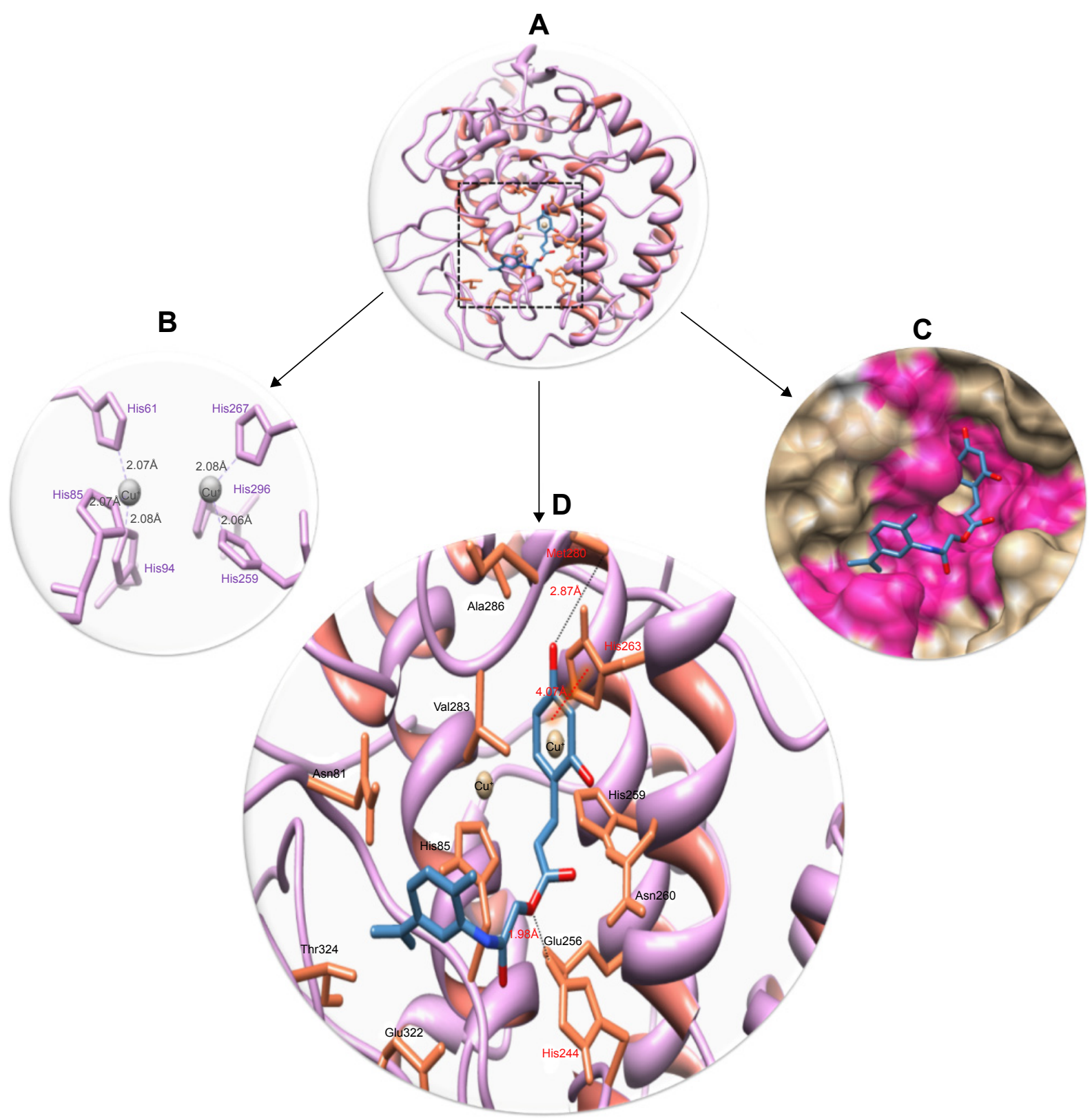

Figure 10 Docking interactions between $\mathbf{6 d}$ and target protein.

Notes: (A) The 6d docking complex with ligand is in blue color and embedded functional groups such as oxygen and amino are highlighted in red and dark blue colors, respectively. The protein structure is represented in purple color while interior helices are depicted in brown color. (B) Six copper-interacted residues lie within the active region of target protein and are represented in purple color. (C) The binding pocket of target protein in surface format is represented in dark purple color with conformational position of ligand. (D) Closer view of docking interaction. The active binding site amino acids are highlighted in brown color. Two copper ions are also represented in gray color. Two hydrogen bonds and one $\pi-\pi$ interaction were observed between $\mathbf{6} \mathbf{d}$ and receptor amino acids such as His244, Met280 and His 363 with bonding distances 1.98, 2.87, and 4.07Å, respectively. Interacted residues are in red color labels.

throughout MD trajectories thus increasing the efficacy of docking results.

The compactness of the target protein was measured by radius of gyration $(\mathrm{Rg})$. The results obtained for both $\mathbf{6 a}$ and $\mathbf{6 d}$ showed that the Rg value underwent a little fluctuation between 2 and $2.03 \mathrm{~nm}$ throughout the simulation time $0-15$ ns. These results justified that the residual backbone and folding of the receptor protein $\mathbf{6} \mathbf{d}$ was comparatively stable compared with $\mathbf{6 a}$. The Rg values and graph lines of 6a and $\mathbf{6 d}$ are shown in Figure 13. The solvent accessible surface area and dihedral pattern (Chi) of the target protein are given in Figures S12 and S13.

\section{Conclusion}

Hydroxylated amide derivatives $4 \mathbf{4}-\mathbf{e}$ and $\mathbf{6 a}-\mathbf{e}$ were synthesized following simple reaction routes with excellent yields as melanogenesis inhibitors. The in vitro, in vivo and computational studies proved that compound $\mathbf{6 d}$ is a highly potent melanogenesis inhibitor compared to standard kojic acid. Among the synthesized amides, $\mathbf{6 d}$ showed excellent 


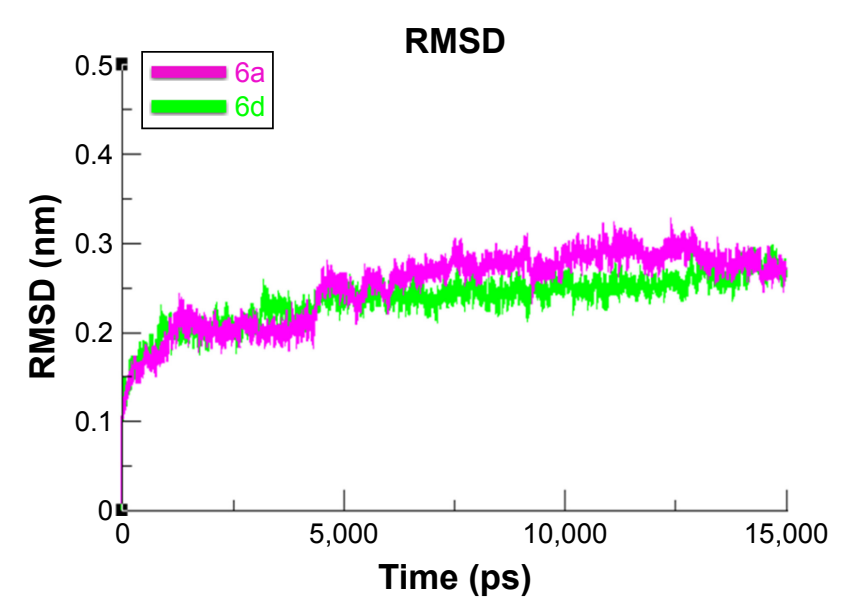

Figure I I RMSD graph of $\mathbf{6} \mathbf{a}$ and $\mathbf{6 d}$ at 15 ns.

Note: The graph lines with purple and green colors represent $\mathbf{6} \mathbf{a}$ and $\mathbf{6} \mathbf{d}$ complexes, respectively.

Abbreviation: RMSD, root mean square deviation.

mushroom tyrosinase inhibitory activity $\left(\mathrm{IC}_{50} 0.15 \mu \mathrm{M}\right)$ compared to standard kojic acid ( $\left.\mathrm{IC}_{50} 16.69 \mu \mathrm{M}\right)$. The enzyme inhibition kinetics determined by Lineweaver-Burk plots showed that compounds $\mathbf{4 c}$ and $\mathbf{6 d}$ exhibited noncompetitive inhibition, while $\mathbf{6} \mathbf{a}$ and $\mathbf{6 b}$ exhibited mixed-type inhibitions. The kinetic mechanism further revealed that compound $\mathbf{6 d}$ formed irreversible complex with the target enzyme tyrosinase. The $K i$ values of compounds $4 \mathbf{c}, \mathbf{6 a}, \mathbf{6 b}$ and $\mathbf{6 d}$ were $0.188 \mu \mathrm{M}, 0.84 \mu \mathrm{M}, 2.20 \mu \mathrm{M}$ and $0.217 \mu \mathrm{M}$, which shows that compound $\mathbf{6} \mathbf{d}$ possessed stronger binding capacity. The same compound $\mathbf{6 d}$ also showed an inhibitory activity of $91.9 \%$ on human tyrosinase. The in vivo cytotoxicity evaluation of $\mathbf{6} \mathbf{d}$ in zebrafish embryos showed that it is non-toxic to zebrafish. The melanin depigmentation

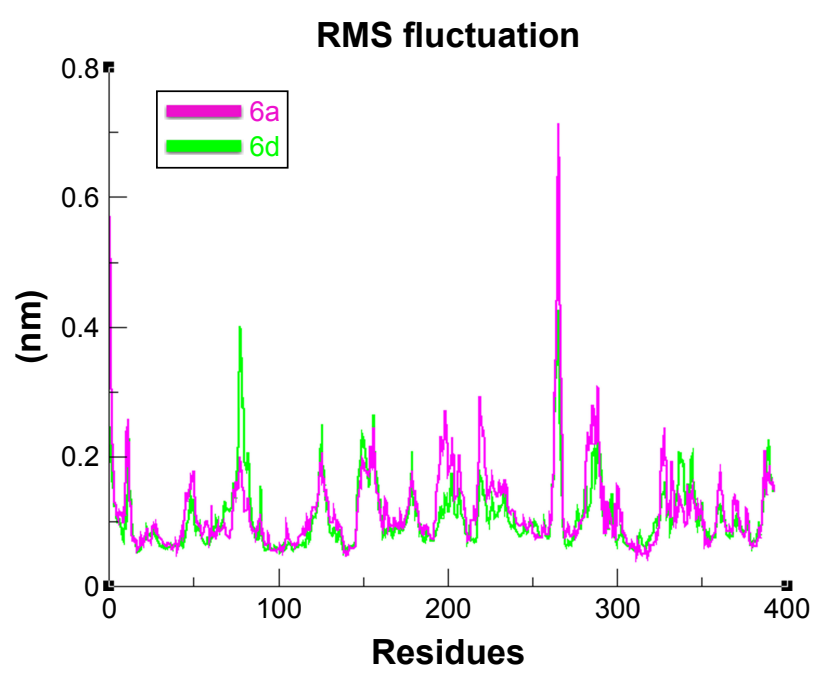

Figure 12 RMSF graph of $\mathbf{6 a}$ and $\mathbf{6} \mathbf{d}$ at 15 ns.

Note: The graph lines with purple and green colors represent $\mathbf{6} \mathbf{a}$ and $\mathbf{6} \mathbf{d}$ complexes, respectively.

Abbreviation: RMSF, root mean square fluctuation.

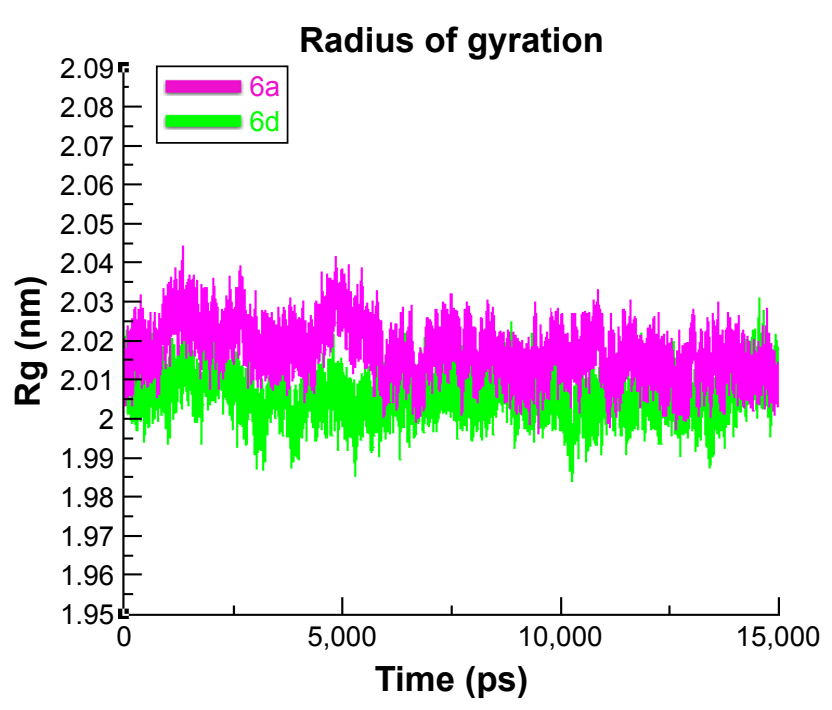

Figure 13 Radius of gyration $(\mathrm{Rg})$ graphs of $\mathbf{6 a}$ and $\mathbf{6 d}$ : bound and unbound formats.

Note: The graph lines with green and purple represent the bound and unbound target protein, respectively.

assay in zebrafish indicated that compound $\mathbf{6} \mathbf{d}$ had a greater potential in decreasing melanin contents compared to kojic acid at same concentration. The computational studies also supported the wet lab findings as the compound $\mathbf{6 d}$ exhibited highest binding affinity with the target protein (PDBID: 2 Y9X) with a binding energy value of $-7.90 \mathrm{kcal} / \mathrm{mol}$. The MD simulation studies also proved that amide $\mathbf{6 d}$ formed the most stable complex with tyrosinase. Based upon our in vitro, in vivo and computational studies, we propose that compound $\mathbf{6} \mathbf{d}$ is a promising candidate for the development of safe cosmetic agent.

\section{Disclosure}

The authors report no conflicts of interest in this work.

\section{References}

1. Levy C, Khaled M, Fisher DE. MITF: master regulator of melanocyte development and melanoma oncogene. Trends Mol Med. 2006;12(9): 406-414.

2. Lin JY, Fisher DE. Melanocyte biology and skin pigmentation. Nature. 2007;445(7130):843-850.

3. Raj D, Brash DE, Grossman D. Keratinocyte apoptosis in epidermal development and disease. J Invest Dermatol. 2006;126(2):243-257.

4. Sánchez-Ferrer A, Rodríguez-López JN, García-Cánovas F, GarcíaCarmona F. Tyrosinase: a comprehensive review of its mechanism. Biochem Biophys Acta. 1995;1247(1):1-11.

5. Van Holde KE, Miller KI, Decker H. Hemocyanins and invertebrate evolution. J Biol Chem. 2001;276(19):15563-15566.

6. Solminski A, Constantino R. L-tyrosine induces tyrosinase expression via a post transcriptional mechanism. Experientia. 1991;47(7):721-724.

7. Solminski A, Constantino R. Molecular mechanism of tyrosinase regulation by L-dopa in hamster melanoma cells. Life Sci. 1991;48(21): 2075-2079.

8. Slominski A, Paus R. Are L-tyrosine and L-dopa hormone-like bioregulators? J Theor Biol. 1990;143(1):123-138. 
9. Prota G. Melanins and Melanogenesis. New York: Academic Press Inc; 1992.

10. Prota G. The chemistry of melanins and related metabolites. Fortsch Chem Organ Natur. 1995;64:93-148.

11. Kadekaro AL, Kanto H, Kavanagh R, Abdel-Malek ZA. Significance of the melanocortin 1 receptor in regulating human melanocytes pigmentation, proliferation and survival. Ann N Y Acad Sci. 2003;994: 359-365.

12. Petit L, Pierard GE. Skin-lightening products revisited. Int J Cosmet Sci. 2003;25(4):169-181.

13. Riley PA. Melanogenesis and melanoma. Pigment Cell Res. 2003;16(5): 548-552.

14. Uong A, Zon LI. Melanocytes in development and cancer. J Cell Physiol. 2010;222(1):38-41.

15. Yamaguchi Y, Hearing VJ. Melanocytes and their diseases. Cold Spring Harb Perspect Med. 2014;4(5):pii:a017046.

16. Lynde CB, Kraft JN, Lynde CW. Topical treatments for melasma and postinflammatory hyperpigmentation. Skin Therapy Lett. 2006; 11(9):1-6.

17. Asanuma M, Miyazaki I, Ogawa N. Dopamine- or L-DOPA induced neurotoxicity: the role of dopamine quinone formation and tyrosinase in a model of Parkinson's disease. Neurotox Res. 2003;5(3): $165-176$

18. Zhu YJ, Zhou HT, Hu YH, et al. Antityrosinase and antimicrobial activities of 2-phenylethanol, 2-phenylacetaldehyde and 2-phenylacetic acid. Food Chem. 2011;124(1):298-302.

19. Xu Y, Stokes AH, Roskoski R Jr, Vrana KE. Dopamine, in the presence of tyrosinase, covalently modifies and inactivates tyrosine hydroxylase. J Neurosci Res. 1998;54(5):691-697.

20. Menezes JC, Kamat SP, Cavaleiro JA, Gaspar A, Garrido J, Borges F. Synthesis and antioxidant activity of long chain alkyl hydroxycinnamates. Eur J Med Chem. 2011;46(2):773-777.

21. Miliovsky M, Svinyarov I, Mitrev Y, et al. A novel one-pot synthesis and preliminary biological activity evaluation of cis-restricted polyhydroxy stilbenes incorporating protocatechuic acid and cinnamic acid fragments. Eur J Med Chem. 2013;66:185-192.

22. Liu XD, Huang H, Chen QX. Studies on inhibitory effects of benzoic acid on mushroom tyrosinase. J Xiamen Univ Natur Sci. 2003;42(1): $102-106$

23. Chen QX, Song KK, Qiu L, Liu XD, Huang H, Guo HY. Inhibitory effects on mushroom tyrosinase by p-alkoxybenzoic acids. Food Chem. 2005;91(2):269-274.

24. Takahashi T, Miyazawa M. Synthesis and structure-activity relationships of phenylpropanoid amides of serotonin on tyrosinase inhibition. Bioorg Med Chem Lett. 2011;21(7):1983-1986.

25. Ashraf Z, Rafiq M, Seo SY, Babar MM, Zaidi NSS. Design, synthesis and bioevaluation of novel umbelliferone analogues as potential mushroom tyrosinase inhibitors. J Enzyme Inhib Med Chem. 2015;30(6) 874-883.

26. Kraunsoe JA, Claridge TD, Lowe G. Inhibition of human leukocyte and porcine pancreatic elastase by homologues of bovine pancreatic trypsin inhibitor. Biochemistry. 1996;35(28):9090-9096.

27. Kim SJ, Sancheti SA, Sancheti SS, Um BH, Yu SM, Seo SY. Effect of 1, 2, 3, 4, 6-penta-O-galloyl-beta-D-glucose on elastase and hyaluronidase activities and its type II collagen expression. Acta Pol Pharm. 2010;67(2):145-150.

28. Reddy CVK, Sreeramulu D, Raghunath M. Antioxidant activity of fresh and dry fruits commonly consumed in India. Food Res Int. 2010; 43(1):285-288.

29. Ashraf Z, Rafiq M, Seo SY, Babar MM, Zaidi NSS. Synthesis, kinetic mechanism and docking studies of vanillin derivatives as inhibitors of mushroom tyrosinase. Bioorg Med Chem. 2015;23(17): 5870-5880.

30. Ashraf Z, Rafiq M, Seo SY, Kwon KS, Babar MM, Zaidi NSS. Kinetic and in silico studies of novel hydroxy-based thymol analogues as inhibitors of mushroom tyrosinase. Eur J Med Chem. 2015;98: 203-211.
31. Sugimoto K, Nishimura T, Nomura K, Sugimoto K, Kuriki T. Syntheses of arbutin-alpha-glycosides and a comparison of their inhibitory effects with those of alpha-arbutin and arbutin on human tyrosinase. Chem Pharm Bull (Tokyo). 2003;51(7):798-801.

32. Funayama M, Nishino T, Hirota A, Murao S, Takenishi S, Nakano H. Enzymatic synthesis of $(+)$ catechin- $\alpha$-glucoside and its effect on tyrosinase activity. Biosci Biotech Biochem. 1993;57(10): 1666-1669.

33. Choi T-Y, Kim J-H, Ko DH, et al. Zebrafish as a new model for phenotype-based screening of melanogenic regulatory compounds. Pigment Cell Res. 2007;20(2):120-127.

34. Hsu KD, Chen HJ, Wang CS, et al. Extract of Ganoderma formosanum mycelium as a highly potent tyrosinase inhibitor. Sci Rep. 2016;6:32854

35. Baek SH, Lee SH. Sesamol decreases melanin biosynthesis in melanocyte cells and zebrafish: possible involvement of MITF via the intracellular cAMP and p38/JNK signalling pathways. Exp Dermatol. 2015;24(10):761-766.

36. Thompson MJ, Louth JC, Ferrara S, et al. Discovery of 6-substituted indole-3-glyoxylamides as lead antiprion agents with enhanced cell line activity, improved microsomal stability and low toxicity. Eur J Med Chem. 2011;46(9):4125-4132.

37. Pettersen EF, Goddard TD, Huang CC, et al. UCSF Chimera - a visualization system for exploratory research and analysis. J Comput Chem. 2006;25(13):1605-1612.

38. Lovell SC, Davis IW, Arendall WB 3rd, et al. Structure validation by Calpha geometry: phi, psi and Cbeta deviation. Proteins. 2002;50(3): 437-450.

39. Chen VB, Arendall WB 3rd, Headd JJ, et al. MolProbity: all-atom structure validation for macromolecular crystallography. Acta Crystallogr D Biol Crystallogr. 2010;66(Pt 1):12-21.

40. Discovery Studio. Version 2.1. San Diego, CA: Accelrys; 2008. Available from: http://accelrys.com/products/collaborative-science/ biovia-discovery-studio/requirements/technical-requirements-450.html. Accessed June 1, 2017.

41. Willard L, Ranjan A, Zhang H, et al. VADAR: a web server for quantitative evaluation of protein structure quality. Nucleic Acids Res. 2003; 31(13):3316-3319.

42. Dallakyan S, Olson AJ. Small-molecule library screening by docking with PyRx. Methods Mol Biol. 2015;1263:243-250.

43. Wallace AC, Laskowski RA, Thornton JM. LIGPLOT: a program to generate schematic diagrams of protein-ligand interactions. Protein Eng. 1996;8(2):127-134.

44. Pronk S, Pall S, Schulz R, et al. GROMACS 4.5: a high-throughput and highly parallel open source molecular simulation toolkit. Bioinformatics. 2013;29(7):845-854.

45. Chiu SW, Pandit SA, Scott HL, Jakobsson E. An improved united atom force field for simulation of mixed lipid bilayers. J Phys Chem B. 2009; 113(9):2748-2763.

46. Schüttelkopf AW, van Aalten DMF. PRODRG: a tool for high-throughput crystallography of protein-ligand complexes. Acta Crystallogr D Biol Crystallogr. 2004;60(Pt 8):1355-1363.

47. Wang H, Dommert F, Holm C. Optimizing working parameters of the smooth particle mesh Ewald algorithm in terms of accuracy and efficiency. J Chem Phys. 2010;133(3):034117.

48. Amiri S, Sansom MS, Biggin PC. Molecular dynamics studies of AChBP with nicotine and carbamylcholine: the role of water in the binding pocket. Protein Eng Des Sel. 2007;20(7):353-359.

49. Ashraf Z, Alamgeer, Rasool R, et al. Synthesis, bioevaluation and molecular dynamic simulation studies of dexibuprofen-antioxidant mutual prodrugs. Int J Mol Sci. 2016;17(12):2151.

50. Chen Z, Cai D, Mou D, et al. Design, synthesis and biological evaluation of hydroxy- or methoxy-substituted 5-benzylidene (thio) barbiturates as novel tyrosinase inhibitors. Bioorg Med Chem. 2014;22(13): 3279-3284.

51. Veldman MB, Lin S. Zebrafish as a developmental model organism for pediatric research. Pediatr Res. 2008;64(5):470-476. 
52. Kadam RU, Roy N. Recent trends in drug-likeness prediction: a comprehensive review of in silico methods. Indian J Pharm Sci. 2007;69: 609-615.

53. Bakht MA, Yar MS, Abdel-Hamid SG, Al-Qasoumi SI, Samad A. Molecular properties prediction, synthesis and antimicrobial activity of some newer oxadiazole derivatives. Eur J Med Chem. 2010;45(12): 5862-5869.
54. Tian S, Wang J, Li Y, Li D, Xu L, Hou T. The application of in silico drug-likeness predictions in pharmaceutical research. Adv Drug Del Rev. 2015;86:2-10.

55. Chen WC, Tseng TS, Hsiao NW, et al. Discovery of highly potent tyrosinase inhibitor, T1, with significant anti-melanogenesis ability by zebrafish in vivo assay and computational molecular modeling. Sci Rep. 2015;5:7995.

\section{Publish your work in this journal}

Drug Design, Development and Therapy is an international, peerreviewed open-access journal that spans the spectrum of drug design and development through to clinical applications. Clinical outcomes, patient safety, and programs for the development and effective, safe, and sustained use of medicines are the features of the journal, which has also been accepted for indexing on PubMed Central. The manuscript management system is completely online and includes a very quick and fair peer-review system, which is all easy to use. Visit http://www.dovepress.com/testimonials.php to read real quotes from published authors.

Submit your manuscript here: http://www.dovepress.com/drug-design-development-and-therapy-journal 